\title{
Research
}

\section{Participatory Scenario Planning for Protected Areas Management under the Ecosystem Services Framework: the Doñana Social-Ecological System in Southwestern Spain}

\author{
$\underline{\text { Ignacio Palomo }}^{1}, \underline{\text { Berta Martín-López }}^{1,2}$ Cesar López-Santiago $^{1}$, and Carlos Montes $^{1}$
}

\begin{abstract}
Conservation and development visions in and around protected areas generate confrontation and uncertainty that damage the biodiversity and ecosystem services which maintain human well-being. To address this issue, we applied the participatory scenario planning framework to the protected area of the Doñana social-ecological system in southwestern Spain. This work explores the social perceptions regarding the conditions, trends, trade-offs, and future of ecosystem services and human well-being, and seeks management strategies for the Doñana social-ecological system and its protected areas. We found that participatory scenario planning (1) can create different visions of the future of the system addressing its uncertainty and the main ecosystem services trade-offs, and (2) can propose consensual management strategies to determine a path toward a desirable future.
\end{abstract}

Key Words: backcasting; Doñana social-ecological system; ecosystem services; multi-scale scenarios; participatory scenario planning; protected areas management; social-ecological system; Spain

\section{INTRODUCTION}

When conservation strategies for protected areas follow a top-down approach that excludes local practices or interests, conflict can emerge (West et al. 2006). Additionally, the lands surrounding protected areas often become degraded and suffer quick transformations of land use (Defries et al. 2005, Naughton-Treves et al. 2005). As a consequence, a conflicting vision emerges that pits economic development against conservation. Local people might lose the ownership, use, and management rights over land inside the protected area, but may continue to see the protected area and its surroundings as an economic resource, while conservationists and visitors seek to protect and enjoy the natural areas that remain.

Although successful in the short term, it's time to overcome the command and control approach to the protection of nature (Holling and Meffe 1996, Ludwig 2001). Over the last few decades, many have argued that local communities should participate in the management of the local environment in general (Gunderson et al. 1995,
Berkes 2003) and of protected areas in particular (Pimbert and Pretty 1997, Warner 1997, Phillips 2003). It is now recognized that the sustainable management of natural resources cannot be achieved without the involvement of the affected communities (Ribot 2002, Pretty 2003). The main reasons for their participation in environmental management are as follows: the democratization of management (Elster 1998); involving and empowering participants (Tippett et al. 2007); the coproduction of knowledge between experts and users (Roux et al. 2006); improving the community/ protected area relationship (Méndez-Contreas et al. 2008); reaching consensus among stakeholders and developing a common vision of the future (Baker et al. 2004); and increasing the effectiveness of environmental management projects (Reed 2008).

To achieve sustainable governance, stakeholders should reach a consensus about the current situation and future goals in a platform that allows social learning (Rist et al. 2007). Participatory scenario planning involves stakeholders in the creation of scenarios to improve decision-making. The dialogue and debate created in this process is one 
of its strengths and this helps to produce a shared vision of the future and a plan to achieve it (Andersen and Jaeger 1999, Brown et al. 2001). In this sense, participatory scenario planning can help create common visions, coproduce knowledge, and foster cooperation between different stakeholders (Andersen and Jaeger 1999, Wollenberg et al. 2000, Biggs et al. 2007).

Scenarios are plausible descriptions of how the future might unfold based on a coherent set of assumptions about key elements and drivers of change (Carpenter et al. 2005). Whether qualitative or quantitative, scenarios are not static snapshots of future events; rather they include a logical sequence of images of the future and drivers of change (Rotmans 2000). In contrast to predictions and models, scenarios explore the uncertainty of future events, and thus decisions based on scenarios provide greater resilience to surprise (Peterson et al. 2003b). In this sense, scenarios bring awareness of future dangers and allow the construction of proactive strategies to adapt management to possible future events (Huss 1988, Wollenberg et al. 2000). Recently, multi-scale scenarios, i.e., those developed at more than one scale, have been applied to state cross-scale connections between processes and people (Biggs et al. 2007, Kok et al. 2007).

The link between scenarios and management is strong. Scenarios are a powerful approach for the engagement of decision-makers (Bohensky et al. 2006), and most are developed with the aim of being used for policy (Wollenberg et al. 2000). Scenarios are increasingly being used in environmental planning to explore different issues related to future development, such as the state of biodiversity (Sala et al. 2000), the emission of greenhouse gases (Nakišenoviš et al. 2000), the evolution of ecosystem services and their relationship to human well-being (Carpenter et al. 2005, 2006; Pereira et al. 2005; Bohensky et al. 2006), desertification and land degradation (Kok et al. 2004), land-use changes and their impacts (Jessel and Jacobs 2005), regional planning (Peterson et al. 2003a), coastal planning under climate change (Tompkins et al. 2008), conservation-development projects (Sandker et al. 2007), research-development projects (Enfors et al. 2008), and the management of natural protected areas (Brown et al. 2001, Gude et al. 2007).

We have developed a participatory scenario planning process to address protected areas management in one of the most important European wetlands: the Doñana protected area in southwestern Spain. Our main aim was to create a plan for managing protected areas where conflict between development and conservation exists, according to the results of the participatory scenario planning process. Secondary aims were to cope with uncertainty and to build consensus for management among the different stakeholders and interests in and around the Doñana protected area. The article also discusses the multi-scale scenario process and how it can be improved, as well as the different participatory techniques adopted.

\section{THE DÕ̃ANA SOCIAL-ECOLOGICAL SYSTEM}

The Doñana region (hereafter Doñana) is located at the end of the Guadalquivir watershed, which is situated in Andalusia on the southwestern coast of Spain. Far from being pristine, Doñana has been greatly influenced by activities in its territory throughout its history (Ojeda-Rivera 1987). The antiquity of practices such as agriculture, forestry, grazing, or fire management in Doñana allows us to describe it as a cultural landscape where nature and society have co-evolved in time and space (OjedaRivera 1990, Gómez-Baggethun et al. 2010). Therefore, as done previously in other studies (Martín-López et al. 2007a), Doñana can be conceptualized as a social-ecological system of humans in nature (sensu Berkes and Folke 1998, Anderies al. 2004).

The Doñana social-ecological system (Fig. 1) consists of an ecological system and a social system. The boundaries of both systems have been drawn according to previous literature and expert criterion. The ecological system has been described as the Greater Fluvial-Littoral Ecosystem of Doñana, which contains four ecodistricts-marshes, aeolian sheets, coast, and estuary - extending over a 2205$\mathrm{km}^{2}$ area (Montes et al. 1998). The marshes of Doñana are considered one of the most important wetlands in Europe and one of the key European stopovers in bird migration routes and in which $75 \%$ of European birds can be found (FernándezDelgado 1997). The social system includes the municipalities that depend on the natural capital of Doñana. It extends over an area of $3115 \mathrm{~km}^{2}$ and has a population of 175,200 people. It includes 12 municipalities within three provinces: Huelva (Almonte, Hinojos, Lucena del Puerto, Moguer), 
Seville (Aznalcázar, Isla Mayor, La Puebla del Río, Lebrija, Pilas, Villamanrique de la Condesa), and Cádiz (Trebujena, Sanlúcar de Barrameda). Agriculture and tourism are the main resources of income for the region, and the main institutions are the regional ministries of environment, agriculture, and tourism; the Andalusian Water Agency; the municipal governments; the farmers associations; the Doñana Biological Station (an institution for biological research); the Foundation Doñana 21 (an institution created in 1992 to promote sustainable development in the region); and some environmental NGOs.

The importance of Doñana for conservation is reflected in the different categories of protection that exist in Doñana, i.e., international (UNESCO Biosphere Reserve and World Heritage Site, Ramsar Wetland of International Importance), European (Site of Community Importance), national (national park), and regional (Natural Park, Protected Landscape, Natural Monument, Natural Place, Natural Reserve). The main ecosystem services provided by the Doñana social-ecological system are: provisioning (i.e., agriculture, grazing, shellfish gathering, hunting), regulating (i.e., air and water purification, water regulation, carbon sequestration, soil fertility), and cultural (i.e., nature tourism, satisfaction for biodiversity, sightseeing, beach tourism, and religious tourism). The main local and regional ecological threats that Doñana faces nowadays are contamination, intensive agriculture, and the development of the road network (mainly for tourism) that fragments the territory and threats the existence of endangered species such as the Iberian lynx (Carmona and Fuentelsaz 2006). But there are also global threats such as desertification and climate change that could affect Doñana in the upcoming decades (Fernández and Borja-Barrera 2006). A recent driver in the region is an increase in population due to immigration that is mainly related to agriculture.

Fig. 2 represents the evolution of the Doñana socialecological system related to the conservation vs. development conflict and its current uncertainty. In the following lines we describe the recent evolution of the system and some consequences. In 1969, the Doñana National Park was created to protect natural habitats from rapid agricultural transformations that were draining many marshes. In 1989, the Natural Park was created, and then, the National Park and the Natural Park were unified in 2005 as the Doñana Natural Area, covering $1081 \mathrm{~km}^{2}$, or $50 \%$ of the Doñana ecological system area. Other protected areas, such as Protected Landscapes or Natural Monuments, coexist in the region. The declaration of the protected areas, especially the National Park, permitted the protection of an area of great value, but it also brought one of the threats that the declaration of a protected area often entails: the territory inside the park boundary was viewed as a conservation island with no relation to society, while the area outside of the protected area received the right to be degraded (Ojeda-Rivera 1999). This produced two conflicting visions: conservation inside the protected area and development outside of it, resulting in a vision of two different Doñanas (Fernandez-Delgado 1997). This conflict has resulted in the following consequences:

1. A quick transformation of the territory outside the protected areas (Weber et al. 2008), especially the marshes outside the National Park, for agriculture (GonzálezArteaga 1993, Corominas 1995).

2. A feeling among rural communities of being excluded from the property, use, and management of the protected areas (OjedaRivera 1999).

3. The protected areas being influenced by uses in the surrounding areas, e.g., the extraction of water for agriculture from wells outside the protected areas have affected the aquifer under the protected areas; tourism and infrastructure have exerted pressure on the ecosystem; and the estuary may be salinized due to the construction of dams upstream (Fernández-Delgado 1997).

Conflict between conservation and development has existed in Doñana since the first conservation movement in the 1950s, but especially since the declaration of the National Park in 1969 (AtienzaSerna 2001, Van der Zouwen 2006), in part due to the initial top-down conservationism and political authoritarianism (Aguilar Fernández 2008). One of these difficulties has been a desire on the part of the local population for development that conflicts with use restrictions in protected areas. This desire was evident in the late 1980s when the Costa Doñana project was conceived (an urbanization project for 20,000 people in lands near the National Park), although this project was finally rejected. After the rejection, the regional government acknowledged that an all-encompassing and long-term solution for Doñana was needed (Aguilar Fernández 2008). 
Fig. 1. The Doñana social-ecological system, and the ecodistricts that constitute the Greater FluvialLittoral Ecosystem of Doñana. The semi-natural ecodistricts are those ecosystems modified by human use throughout history in a process of co-evolution. Transformed ecodistricts are those that have suffered a great modification (degradation) in the second half of the 20th century, mainly due to the introduction of agriculture, forest plantations, or aquiculture. Sample points are those places where interviews and questionnaires were made. The main use in the white areas is agriculture.

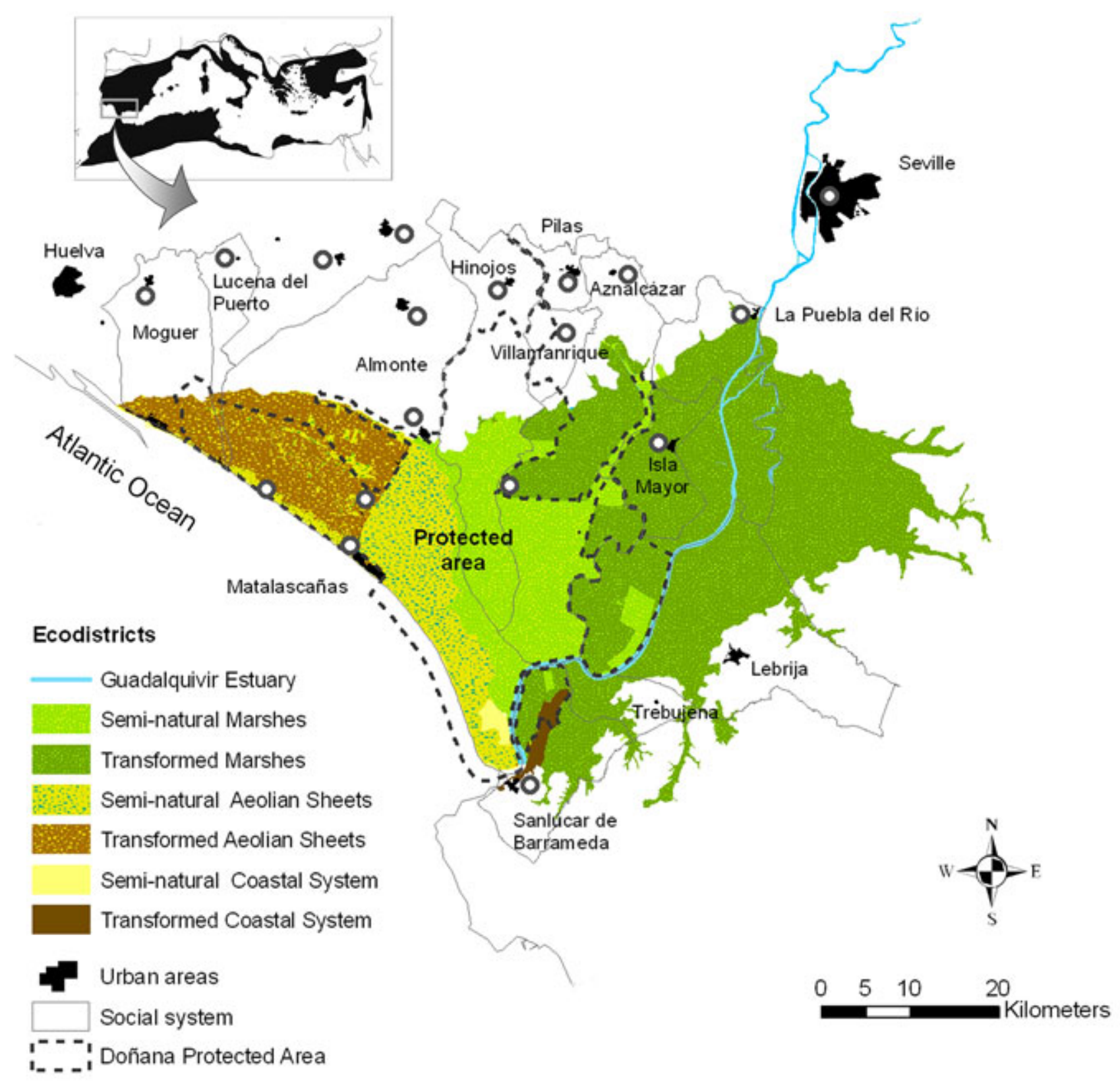


Fig. 2. Schematic illustration of the evolution of the Doñana social-ecological system attending to the conservation vs. development conflict. The X-axis symbolizes time, where the main stages of the Doñana social-ecological system are reflected. The main events regarding the conservation vs. development conflict are represented in boxes. Adapted from Enfors et al. 2008.

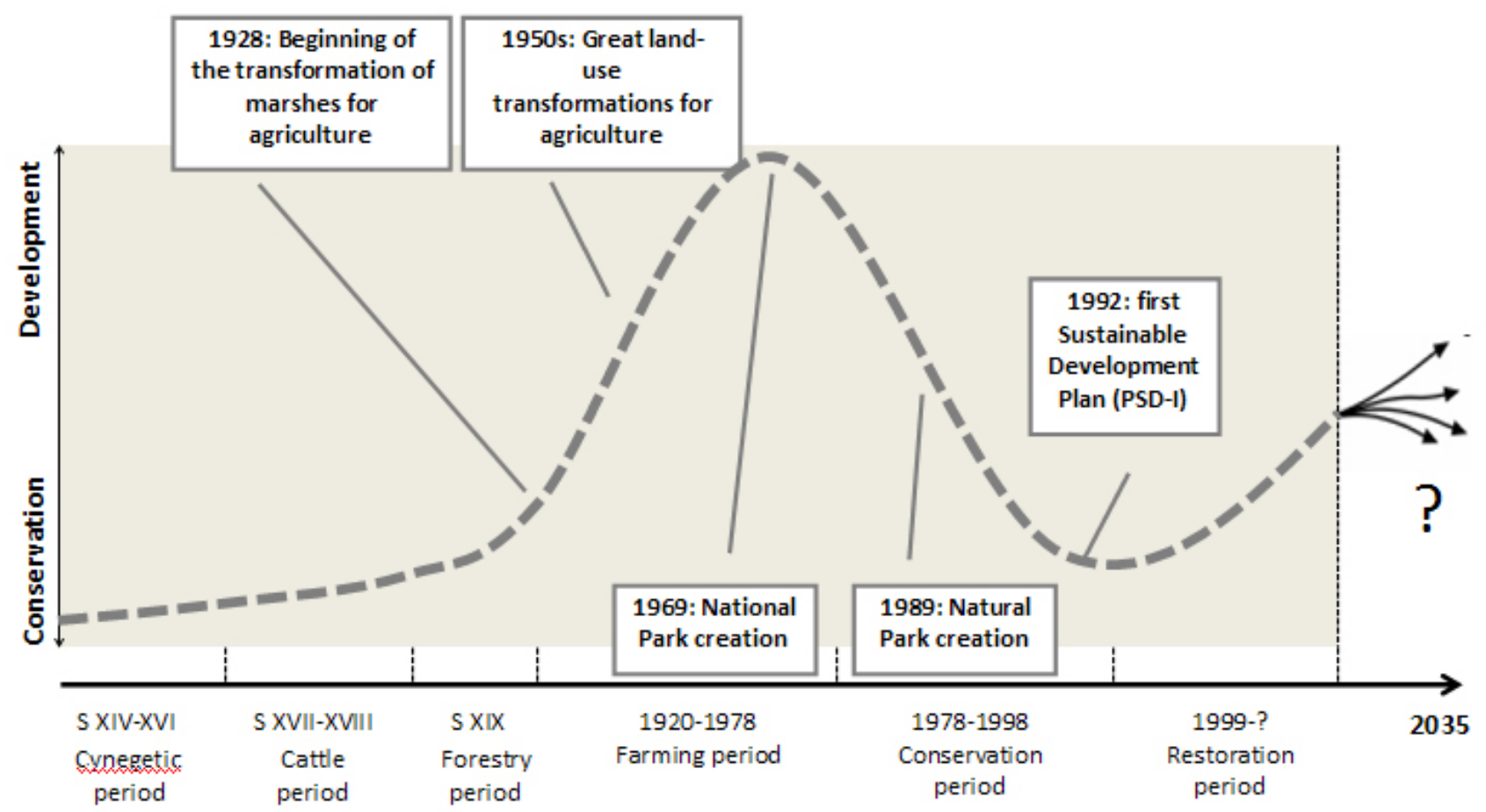

The first Plan for Sustainable Development in Doñana was approved by the European Commission and lasted from 1993 to 2000. This plan provided more than 372 million Euros to the socioeconomic area influenced by the protected areas. The economic growth (infrastructures for tourism and greenhouse-based agriculture) created by the plan reduced the opposition to conservation and helped foster an environmental awareness among the local population, but it also generated new expectations of development for the area (Oñate et al. 2003). In this sense, the first Plan for Sustainable Development in Doñana has not shortened the gap between the conservation and development visions.

The conservation vs. development conflict is also reflected in people's perceptions, especially among those people who are against conservation, although this tendency is diminishing. Some of the local population feel that conservation is one of the most important activities in the Doñana social-ecological system and they perceive that the majority of the funds destined for conservation are spent on the charismatic species of the Iberian lynx (Lynx pardinus) and the Spanish Imperial eagle (Aquila adalberti), which is a view supported by analytical studies (Martín-López et al. 2009a). The restrictive species conservation policies reduce access to protected areas and therefore reduce public support for conservation. In Doñana National Park, restricted access has heightened local opposition toward conservation policies, and local preferences for nonprovisioning services have become less important (Martín-López et al. 2007a). Although the protected areas of Doñana are one of the most ecologically important and highly controversial areas in Europe, very little attention has been given to users' opinions and preferences (Elbersen 2001). 
Initiatives to close the gap between conservation and development have arisen independently from both the development and conservation approaches. From the side of conservation, traditional uses such as grazing, honey collection, shellfish gathering, and pine kernel collection have been allowed under command and control regulation inside the National Park. From the side of development, producers have focused on the quality of products instead of their quantity and have incorporated ecological agriculture or nature tourism, but these changes have been slow. On the one hand, although integrated agricultural production has been widely implemented, ecological agriculture accounted for less than $1 \%$ of the agriculture in Doñana in 2003 (Atienza Serna et al. 2003). On the other hand, nature tourism could be of great importance in Doñana, but it is still a secondary activity compared to sun and beach tourism or religious and cultural tourism due to the National Park access restrictions and territorial planning (Doctor 2009, MartínLópez et al. 2009b).

Today, 40 years after the creation of the National Park, the division between conservation and development is clearly reflected in land uses; outside the protected areas, intensive agriculture is common, and inside the National Park, land uses are restricted or regulated to promote conservation and science. The conservation vs. development division is also reflected in the provision of ecosystem services. Although there are some ecosystem uses that generate provisioning services and are allowed inside the National Park, such as grazing or shellfish gathering, the main provisioning service, agriculture, is conducted outside of the park. Additionally, cultural services such as nature tourism and places to relax are mainly provided outside the National Park due to restrictions that bar entry to the National Park (Martín-López et al. 2009b). On the other hand, scientific investigations are mainly conducted inside the protected areas.

As seen, the Doñana social-ecological system is characterized by complexity, dynamism, and conflict (Ojeda-Rivera and Moral Ituarte 2004). Adverse events have increased the tension and the uncertainty regarding the future of this environmental region, including the Aznalcollar dam spill in 1998 (Grimalt et al. 1999); repeated episodes of bird and fish mortality (Lanzarot Freudenthal 2007); the possible effects of climate change (Fernández and Borja-Barrera 2006), and historically recurrent, high-energy, natural events (tsunamis) (Ruiz et al. 2005).

Many characteristics of the Doñana evolution regarding its wetland and its protected areas can also be seen in other places. Wetlands were generally considered a health hazard and an obstacle to land development that needed to be eliminated, but later, the acknowledgement of wetland functions and value slowed conversion rate (Heimlich et al. 1998). Although few freshwater protected areas have been specifically created to protect wetlands around the world, still they face problems such as land-use disturbances, altered hydrologies, and introduction of nonnative species (Saunders et al. 2002). As freshwater systems are affected by activities taking place upstream in the catchment, increasing landuse changes around protected areas (Hansen et al. 2004, Svancara et al. 2009) will increase negative effects on freshwater protected areas such as Doñana.

\section{METHODS}

The fortieth anniversary of the creation of the National Park (2009) provided the framework for introducing the participatory scenario planning approach for rethinking the management of the Doñana social-ecological system. The data were collected from semistructured interviews, structured questionnaires and scenario workshops. The combination of different participative methods has been recommended for both the management of social-ecological systems and environmental management (Stringer et al. 2006, Lynam et al. 2007) and has previously been successfully applied (see Jessel and Jacobs 2005, Pereira et al. 2005). The combination of these three methodologies allowed us to use a gradual approach to address issues confronting the Doñana social-ecological system and provided complementary results.

We used six stages for the participatory scenario planning process: (1) identification and prioritization of stakeholders; (2) collection of information about those aspects of the system that were important to stakeholders; (3) characterizing past and current conditions and trends; (4) developing a set of scenarios; (5) characterizing the scenarios according to services provided by the ecosystem and human well-being variables; and (6) proposing management strategies to achieve a desirable future through the backcasting process. 


\section{Semi-structured interviews and questionnaires}

We designed semistructured interviews and questionnaires with the aim of identifying the most important stakeholders as well as characterizing the most important ecosystem services provided by the Doñana social-ecological system. We interviewed 32 key informants during a field survey between January and March 2009. We interviewed at least two key informants regarding each of the main activities conducted in the Doñana social-ecological system (agriculture, grazing, shellfish gathering, tourism, religion, scientific research, public administration, protected areas management, and environmental nongovernmental organizations (ENGOs)). The initial findings guided the design of a questionnaire that was used to collect quantitative data regarding the perception of ecosystem services use, ecosystem services vulnerability, protected areas management, and environmental institutions in the Doñana social-ecological system, and regarding the main problems of the region. A total of 183 respondents were surveyed face to face in March 2009. Interviews and surveys used a panel with photographs containing the ecosystem services previously identified in Doñana as explicative material (Weber et al. 2008, Gómez-Baggethun 2010). Both semistructured interviews and questionnaires were carried out in 10 of the Doñana social-ecological system municipalities (Fig. 1) and served as a first step for engaging stakeholders.

\section{Stakeholder selection}

Developing scenarios does not require technical skills, therefore different stakeholder groups such as researchers, managers, or local people can participate in their creation (Kok et al. 2007). Stakeholder groups working together can coproduce knowledge, which might be more effective than the knowledge transfer from experts to managers for managing complex socialecological systems (Roux et al. 2006). Scenario workshops normally include policymakers, business representatives, experts, and citizens (Andersen and Jaeger 1999), but recent projects such as the South African Millennium Ecosystem Assessment (SAfMA) or MedAction have included a wider range of social actors (Kok et al. 2007). We also involved a wide range of stakeholders, including creative people with new ideas (to increase creativity for the scenario development process), local stockbreeders, and experts in traditional ecological knowledge (who, although they were elderly people and unused to participating in workshops, had an important vision of the ecological system as a whole). The presence of a diversity of stakeholders might facilitate the implementation of the results because through their participation stakeholders can get engaged and start to believe in the project (Reed 2008).

Stakeholder selection is complex and of great importance, especially for workshops, because the results will depend on the participants. To avoid selection bias or the marginalization of important stakeholder groups, an analysis of the social actors is recommended instead of an ad hoc selection (Reed et al. 2009). Previous works about social actors in Doñana (Martín-López et al. 2007a, Gómez-Baggethun 2010) greatly facilitated the identification and characterization of stakeholders. Additionally, due to the high diversity of institutions existing in Doñana, we used the institutional network as the basis for creating groups of possible participants, including people from the local and regional government, the Doñana protected areas, research institutions, universities, ENGOs, the media, the religious sector, and professionals from different economic sectors, e.g., tourism, agriculture, grazing, shellfish gatherers, hunters, and other traditional uses. For the prioritization, we followed the importance-influence criterion, which classifies stakeholders according to their importance (if the stakeholder is affected by the decisions that must be made) and their influence (the power of the stakeholder and his control over decisions) (de Groot et al. 2006). We prioritized stakeholders with a medium-high influence in the Doñana socialecological system that were directly affected by its management. For that purpose, we consulted with three experts in the Doñana social-ecological system who belonged to different key institutions (ENGO, university, and Fundación Doñana 21) about which stakeholders had the greatest influences on the system and which were most greatly affected by the system.

\section{Workshops}

We used the participative process to analyze the present use and future evolution of ecosystem services in the area and the consequences for human well-being through four scenarios. Trade-offs among ecosystem services and different variables related to human well-being in the four scenarios were explored to better understand the 
consequences of current actions. Finally, through the backcasting approach, a series of management recommendations were obtained to illustrate a path for achieving a shared vision of a desired future.

\section{First workshop: from the past to the future}

The purpose of the first workshop was twofold: (1) describe the current situation of the Doñana socialecological system and its evolution over the last several decades, and (2) analyze its future development through scenario development. Ninety persons were invited by telephone and email, of which 34 came to the workshop.

In the first step of the scenario-planning process, the participants were asked to list the most important aspects that define the current state of the Doñana social-ecological system. People were asked to write down the main aspects of Doñana on separate cards. Then, the participants were divided into four heterogeneous groups, and the most frequent aspects of each group were analyzed. For the analysis, each participant individually completed a table describing the state of the region on these aspects in the past, the current state, the causes of any change, the main social actors involved in these changes and who benefited from or was harmed by these changes. Then, each of the four groups formed two subgroups where the individual tables were discussed, and two consensus tables were written. Finally, a consensus mural was created in each group from the results of both subgroups. This methodology allowed us to achieve a relatively rapid consensus among all participants where the opinion of each participant had the same value, thereby avoiding biases due to opinion monopolization.

The four groups were then asked to create a set of scenarios for the Doñana social-ecological system. Three groups were given one of the Mediterranean scenarios developed by the MedAction project (see Kok et al. 2004, 2006) and were asked to create a scenario for the Doñana social-ecological system by adapting the Mediterranean scenarios. The fourth group was asked to freely create their desired scenario with the aim of creating a control scenario.

The given MedAction scenarios can be summarized as: (1) Knowledge is King scenario - what if technological development is such that a mass migration to the Mediterranean is initiated and a European sunbelt is formed, while water availability is strongly increased?; (2) Big is Beautiful scenario - what if the "merger principle" oversteps all limits, creating an oversized European Union and powerful multinationals, and thus initiating societal degeneration?; and (3) Convulsive Change scenario - what if climate change is as disruptive as some are now predicting, triggering a series of severe droughts and desert formation, and outpacing society's ability to adapt? (Kok and Rothman 2003).

The degree of linkage between multi-scale scenarios can be described as hard or soft (Zurek and Henrichs 2007). Hard links are recommended to analyze cross-scale processes, while soft links are recommended for participative workshops with local actors (Biggs et al. 2007). We chose a soft link because our aim was to encourage debate and consensus between stakeholders. The link consisted of explaining the Mediterranean scenario and asking participants to describe how the Doñana socialecological system would evolve until 2035 if the explained Mediterranean scenario occurred. The facilitator of each group helped to build a scenario with which everyone in the group felt comfortable. After the main characteristics of the scenario were agreed upon, all four groups created collages to illustrate their scenarios with a set of photographs and newspaper clippings that we provided.

\section{Second workshop: from the future to the present}

The second workshop (32 participants) had two aims: (1) characterizing the scenarios in terms of ecosystem services and different variables related to human well-being, and (2) searching the policy guidelines to reach a desirable future for the Doñana social-ecological system.

For the characterization of scenarios, 17 ecosystem services were chosen, together with different indicators of human well-being, i.e., basic material needs for a good life, health, good social relations, security and freedom of choice, education, equity, employment, and fossil fuel consumption (see Narayan et al. 1999 and Butler et al. 2003). The ecosystem services were previously identified from the semi-structured interviews and questionnaires, as well as from previous literature (Martín-López et al. 2007a, Weber et al. 2008, Gómez-Baggethun 2010).

Four groups were created and each was given a scenario. Participants discussed whether each ecosystem service and social variable would grow, 
fall or remain constant under their scenario. By doing this, stakeholders discussed the trade-offs among ecosystem services and the links between ecosystem services and human well-being. To characterize the scenarios through the participative process, the same procedure as in the first workshop was followed: first, scenarios were characterized individually, then in subgroups of four people, and then the whole group reached a consensus for the scenario characterization. Additionally, after the workshops, the relationship between the provision of ecosystem services and human well-being under the four scenarios was analyzed to see whether there was a correlation between them. After testing the normality of the variables, the Pearson correlation test was applied.

Once scenarios were characterized, participants developed and proposed management strategies that would lead Doñana to a common desired future. This was done using the backcasting approach, which is a common method to analyze how desirable future outcomes can be attained for long-term, complex issues (Dreborg 1996, Carlsson-Kanyama et al. 2008). We maintained the same four working groups, and each was given a theme to facilitate the backcasting process. The themes were selected from the most important aspects that emerged in the first workshop: water, biodiversity, agriculture, and tourism and mobility.

Before the workshop, posters describing each of these aspects in the present and under the future scenarios were prepared by the research team using the outputs of the first workshop (see Fig. 1 of the Appendix). As the descriptions of the future for each aspect differed under each scenario, we asked participants to characterize them as desirable or undesirable future aspects. Then, participants proposed management options (to be applied in the short and medium term) that would lead to a desirable future or avoid an undesirable one. Ideas were individually written on cards and given to the facilitators who grouped them on the posters. These ideas were discussed among participants. After the workshop, the ideas on the cards were counted to see which ideas were more popular among participants.

Participants were given a questionnaire at each workshop to evaluate the utility of the workshops. The main results are shown in Table 1 of the Appendix. Participants were contacted after the workshop and asked to choose their favorite scenario in order to determine their preferences for the future development of the Doñana socialecological system.

\section{RESULTS}

\section{Use and vulnerability of ecosystem services of the Doñana social-ecological system}

Questionnaire results showed that cultural ecosystem services are the most used in the Doñana social-ecological system ( $97 \%$ of people reported benefits from these kind of services), followed by provisioning services (60\% of people reported benefits from these services) and regulating services (55\% of people reported benefits from these services). From all the ecosystem services that were identified as used, 59\% were cultural, $24 \%$ were provisioning, and $17 \%$ regulating. Out of all the ecosystem services perceived as vulnerable, $40 \%$ were provisioning, $34 \%$ were regulating, and $26 \%$ were cultural. Fig. 3 presents the use and vulnerability of ecosystem services of the Doñana social-ecological system to identify the most critical services. In this sense, agriculture and satisfaction for conserving biodiversity have the highest levels of use and vulnerability, making them the most critical ecosystem services to address. Due to their vulnerability, uncertainty exists for these two ecosystem services. Higher levels of use of intensive agriculture could make satisfaction for conserving biodiversity even more vulnerable. On the other hand, higher levels of strict biodiversity conservation could lead to the targeting of agriculture as something harmful for biodiversity, thus increasing its vulnerability. This confirms the hypothesis of conflicting visions at the Doñana social-ecological system: development (agriculture) vs. conservation (biodiversity).

\section{Main aspects of the Doñana social-ecological system and Scenario Zero}

By selecting the most important aspects of the Doñana social-ecological system, the two most important aspects driving change in the Doñana social-ecological system over the last decades were identified as water and biodiversity, which were named by all working groups. The three next most common aspects were land use, protected areas 
Table 1. Main aspects of Doñana, according to the participants of the workshop.

\begin{tabular}{llll}
\hline \hline Aspect & & & \\
Before & Now & Causes of change? & $\begin{array}{l}\text { Main actors } \\
\text { involved }\end{array}$ \\
\hline
\end{tabular}

\section{Water}

Abundant Better quality

Less demand and

less management

\section{Biodiversity}

High

Low conscience

Integrated with the

population

\section{Land use}

Sparsely populated

Isolated

Traditional uses

Without

infrastructure

Local religious

importance

Without feeling a

need for protection

\section{Scarce}

Worst quality

Great demand and

management Critical

aspect
Growth in demand

Less efficient use

\section{Dropping and threatened \\ Bigger conscience \\ Densely populated Connected to the outside \\ New uses \\ Many infrastructures Great growth of Rocío pilgrimage Feeling of a high value place}

Ecosystem transformation Land-use changes Invasive species

Local population Administration

Local population Farmers Administration Tourism and urbanism firms

Farmers (increase of productivity) Private interests of landowners

None

Biodiversity Local population
Resource value enhancement strategy Connection of protected Doñana with surrounding territory
Local population Administration ENGOs

Scientists

Natural Protected

Areas managers
Local population (greater feeling of cohesion and less isolation of Natural Protected Areas)
Local population (limitations to resource use)

\section{Agriculture}

Traditional Dry-farmed Low productivity Local

Diverse in crop varieties

Farmers Administrations European Union Consumers Enterprises
Intermediates Local population (employment generation)
Landscape and biodiversity
Irrigation farming

Highly productive

Oriented to

exportation

Large expansion

Highly dependent on

water

\section{Conservation of protected areas}

$\begin{array}{ll}\text { Bigger natural } & \text { Less natural } \\ \text { "balance" } & \text { "balance" } \\ \text { Less protective } & \text { More protective } \\ \text { regulation } & \text { regulation } \\ \text { Core of natural area } & \begin{array}{l}\text { Larger public space } \\ \text { was private }\end{array} \\ \begin{array}{l}\text { More legal } \\ \text { Conservation not a } \\ \text { theme of concern }\end{array} & \begin{array}{l}\text { protected on } \\ \text { prea }\end{array}\end{array}$

Administration
imposition policy
Growth of
environmental
concern
Conservation
programs Greater
pressure on local
nature

Administration

Local population Environment Administration Scientists ENGOs

Local population (greater knowledge of the value of Doñana)
Local population (limitations to resource use) 
Fig. 3. Dispersion diagram (a plot of the spread of values in a distribution) of the use of ecosystem services and their vulnerability according to respondents. The $\mathrm{x}$ and $\mathrm{y}$ axes represent the ranking of ecosystem services according to these variables. Satisfaction for conserving biodiversity and agriculture have the highest levels of use and vulnerability, making them the most critical ecosystem services to address.

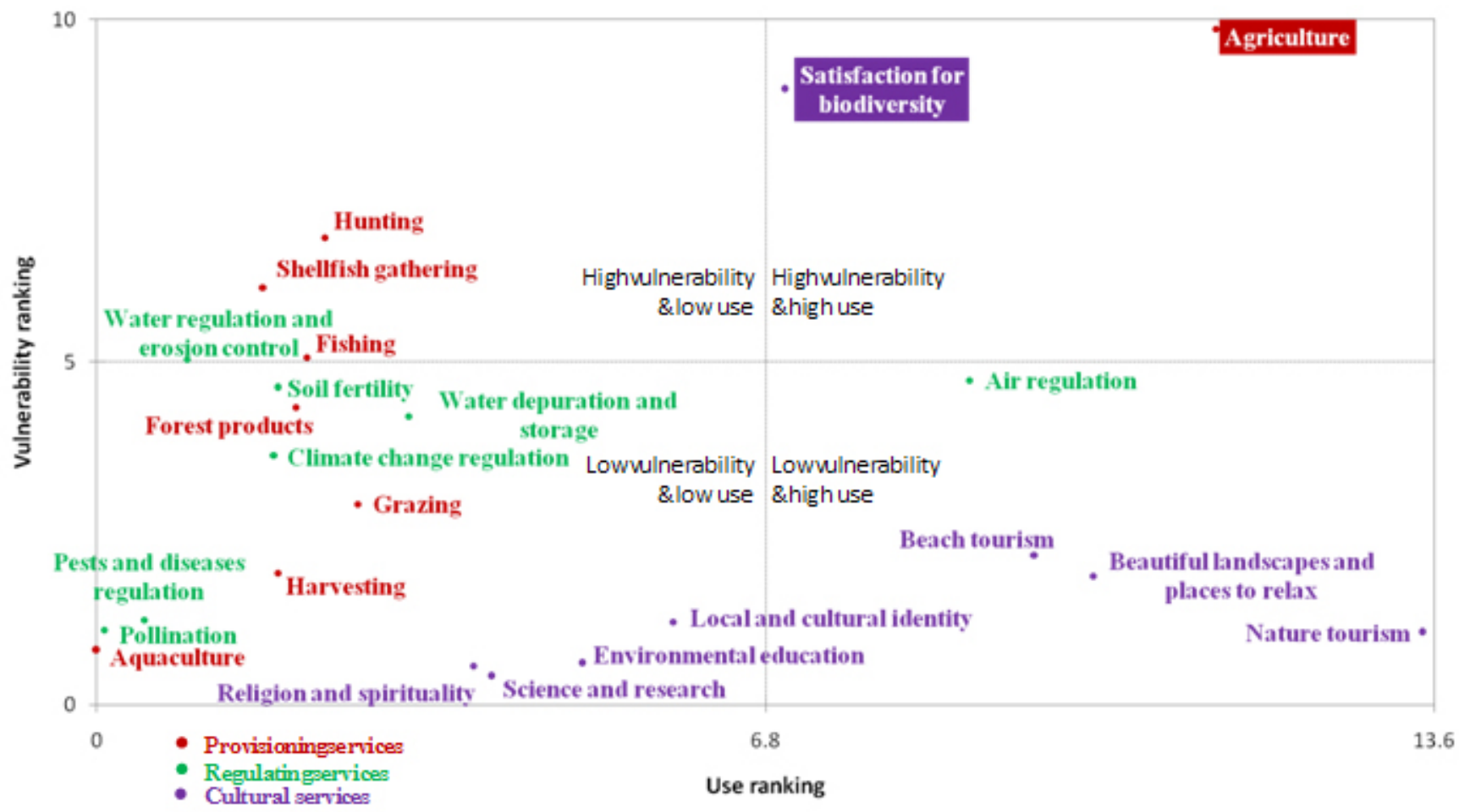

conservation, and agriculture. Table 1 presents the main characteristics of the changes in these five aspects as identified by the participants.

We call Scenario Zero the business as usual scenario. This scenario was created by the research group as a projection of the future based on questionnaires and semi-structured interview results. Under this scenario, Doñana would continue to be a world of contrasting visions (development vs. conservation), with no common identity or idea of sustainability, and in which the local population would not be involved in management. The high demand for water for agriculture would harm biodiversity, and biodiversity itself would be seen in some cases as an impediment to local development. Tourism favored by the protected areas would contribute to the fragmentation of the territory to provide services to visitors, and traditional ecological knowledge could disappear. People benefitting mainly from provisioning services would continue thinking that the protected area does not benefit them, and also that the management of the protected area does not take them into account, as opposed to the who people benefit mainly from regulating and cultural services. (The results of the analysis of contingent tables show that this fact is now significant: $n=134$; $\chi^{2}=12.88 ; p=0.002 ;$ and $n=164 ; \chi^{2}=8.03 ; p=$ 0.018 ). People benefitting mainly from provisioning services would live inside the Doñana socialecological system (96\% of them) while people who 
benefit mainly from cultural services would continue being visitors (58\%). The main problems perceived by Doñana's inhabitants are contamination (21\%), unemployment $(20 \%$,$) and excessive use$ restrictions in the protected area (13\%), which reflect the existence of the confrontation related to the development vs. conservation visions. Cohesion and a common identity would not be achieved, as people would not feel themselves to be "Doñaneros" (what people from Doñana might be called). Only $3 \%$ of questionnaire respondents felt themselves to be "Doñanero", as opposed to "Andalusian" or "Spanish". Finally, the boundaries of "Doñana" would not be the same for everybody; for some (49\%), Doñana would be the whole region, and for others $(36 \%)$ it would be only the protected area.

\section{Future scenarios (2035)}

The four scenarios are presented below with brief storylines. Fig. 4 illustrates the scenarios as inspired by the storylines and the collages made by the participants during the scenario planning process. Central to the figure are biodiversity (the number of different species that can be recognized in the illustrations); the marshes inside the protected area and the surrounding fence; and agriculture and tourism, which are the main issues of the Doñana social-ecological system. These illustrations will be used to communicate the scenarios to the local population. Table 2 describes the drivers, and the main aspects and the main actors of each scenario and of the current situation of the Doñana socialecological system, to allow the scenarios to be compared with the present day. Fig. 2 of the Appendix shows flow diagrams of the scenarios developed after the workshop, which show the interactions among drivers of change and the actors, and it shows main issues of the Doñana socialecological system under each scenario across time.

Scenario 1: Doñana-Global Knowledge (adapted from MedAction's Knowledge is King)

What if technologies of information and communication (TICs) and the development of new sustainable techniques permit solutions to environmental problems and a more informed citizenship participates actively in the management of the Doñana social-ecological system? (see Fig. $4 a)$.

In this scenario, research and new technologies are the main drivers that allow a more sustainable use of Doñana's natural capital. The diffusion of information grows, as well as peoples' awareness about nature, and society becomes more involved in Doñana's management. Agriculture improves because of new inventions such as desalination plants. Tourism becomes more respectful, areas of ecological importance are restored, and biodiversity is maintained. These good conditions attract many immigrants, especially from North Africa.

Scenario 2: Doñana Trademark (adapted from MedAction's Big is Beautiful)

What if globalization and market liberalization allow large international companies to develop operations in Doñana that, with the protection of the European Union, make local institutions less powerful? (see Fig. 4b).

Liberalization of markets promoted by the European Union allows international companies to grow in Doñana and they displace small, local companies. The effects of climate change and unsustainable agriculture policies that seek to maximize benefits affect water reserves and biodiversity inside the protected areas. Some people migrate away from the area due to the worsening environmental and social conditions, and the differences between the rich and poor become more pronounced. Small groups of people that do not support the regime initiate a counter-culture movement that seeks a socially and ecologically sustainable Doñana.

Scenario 3: Arid Doñana (adapted from MedAction's Convulsive Change)

What if the consequences of climate change become so severe that a real environmental crisis takes place that challenges society to cope with its negative effects? (See Fig. 4c.)

Temperature rises and precipitation decreases as consequences of climate change. A great ecological and socioeconomic crisis emerges, mainly due to the lack of water availability. Biodiversity becomes more threatened, water use becomes strictly controlled, agriculture returns to dry crop varieties, and tourism decreases due to rising sea levels. As a consequence, economic funding for research in clean technologies grows, and researchers and ENGO members become social agents of great importance. A new paradigm for sustainability arises. 
Fig. 4. The four scenarios of the Doñana social-ecological system, illustrating the main characteristics of each scenario and the main land uses. (A) Doñana - Global Knowledge features the evolution and implementation of technologies in the Doñana social-ecological system; (B) Doñana Trademark results in intensified agriculture and tourism, as well as social conflicts; (C) Arid Doñana has a lack of water due to climate change, and features the efforts of NGOs to maintain social cohesion; and (D) Adaptive Doñana - Wet and Creative shows a mosaic of uses compatible with sustainability. Feedback between the illustrator and the authors was needed to achieve the final results. Illustration by Antonio Ojea.

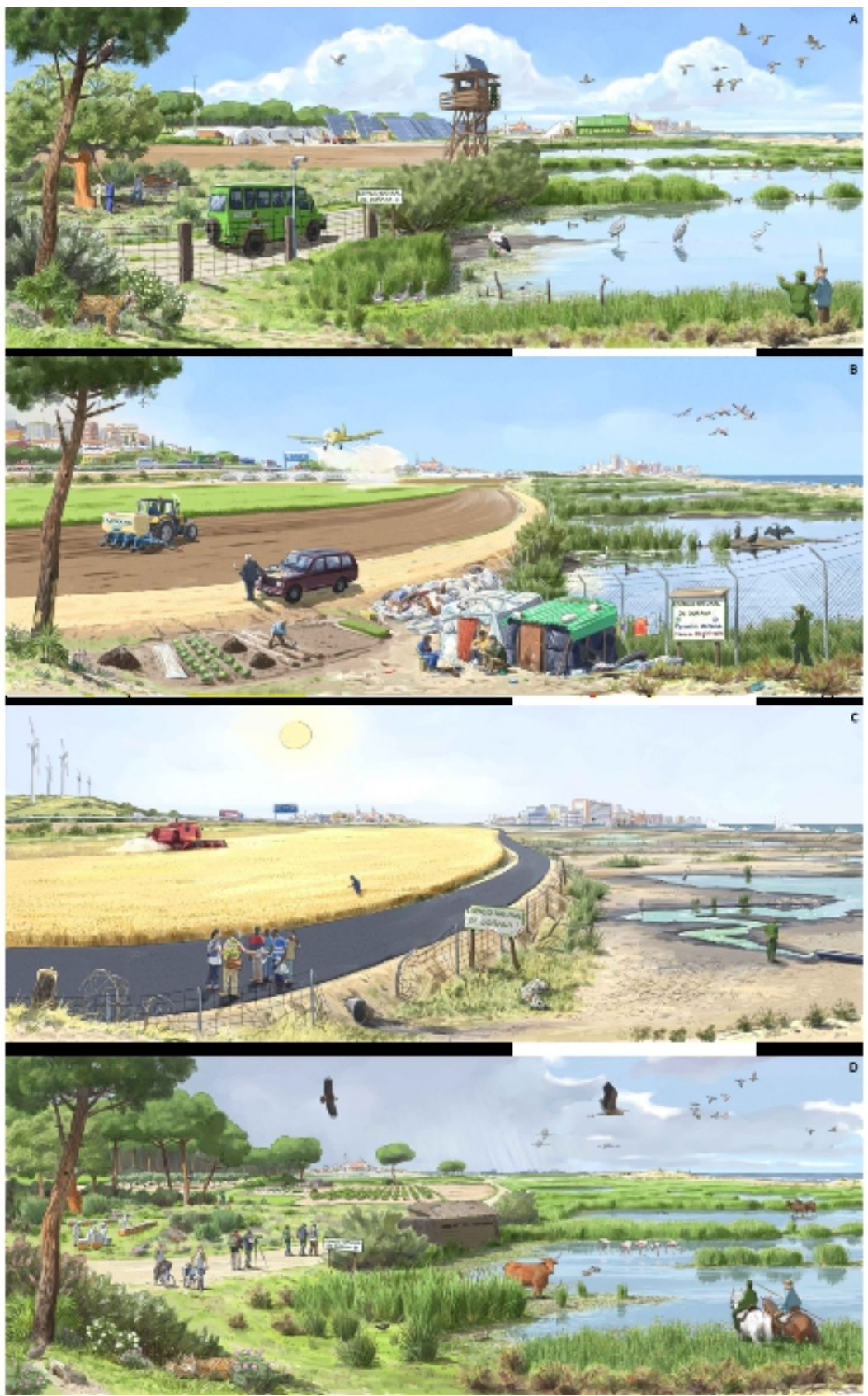


Table 2. Main differences between scenarios attending to drivers, aspects, and social actors. The final column refers to the current situation of the Doñana social-ecological system, to allow the scenarios to be compared with the present day.

\begin{tabular}{|c|c|c|c|c|}
\hline $\begin{array}{c}\text { Scenario 1: } \\
\text { Doñana - Global } \\
\text { Knowledge }\end{array}$ & $\begin{array}{c}\text { Scenario 2: } \\
\text { Doñana Trademark }\end{array}$ & $\begin{array}{l}\text { Scenario 3: } \\
\text { Arid Doñana }\end{array}$ & $\begin{array}{c}\text { Scenario 4: Adaptive } \\
\text { Doñana } \\
\text { - Wet and Creative }\end{array}$ & $\begin{array}{l}\text { Present situation of } \\
\text { the Doñana social- } \\
\text { ecological system }\end{array}$ \\
\hline
\end{tabular}

\section{Drivers}

Technology

Participation

Biodiversity

Conserved due to research improvements and investments

Agriculture

Tourism
Great improvement; desalination plants; green energy; efficient techniques in agriculture

Important for management; linked with technologies of information and communication (TICs)

Few effects; prevention via technology and efficiency

Immigration due to the good social and ecological situations

\section{Aspects}

Water

Better use due to new technologies productive due to technologic advances
Without great improvement; only some to maximize agriculture production

No real participation Not mentioned

Big effects in medium term

Emigration due to the bad social and ecological situations
Improvement after climate change due to the rise in investments in green energy

Emigration due to unemployment after tourism decreases the short term
General improvement; technologies for water efficiency; green energy; alternative public transport

Very important aspect for management; improved through practice and education

Major effects over Few effects

Immigration controlled at the origin through cooperation and development
Some advances, such as solar panels and efficient methods for irrigation, are being installed, but slowly

Becoming more important in Doñana due to initiatives such as the second plan for sustainable development

People show concern for this theme and value the climate regulation ecosystem service

Immigration is growing fast in the region, attracted by agriculture
Higher demand and more squandering; contaminated by agriculture
Scarce due to the fall Management core; in precipitation and technology the increase in temperature; use prioritized to the most important uses improvements for efficient use
Scarce; great demand; management; is a critical aspect because interest groups demand it (farmers for agriculture and conservationists for nature)

Falls due to unsustainable uses; "fortified" Natural

Protected Areas

Decreases due to climate change effects; more protective of the norm

Intensive farming; monoculture; transgenic; unsustainable

Return to dry-farmed Agro-forestry crops due to droughts

Great fall due to the effects of climate change quality tourism
Sustainable and Mass tourism

\section{Conserved through a Tourist and NGO mosaic of landscapes mainly see the importance of endangered flag species}

Important economic sector that employs many workers; slowly incorporating ecological methods helped by new technologies

Alternative, quality, and sustainable tourism
Beach and religious tourism attract more visitors than nature tourism 
Mobility

Low-impact roads

Participate in management and research and sustainable industrial policies

ENGOs
Middle companies

Administration

Scientists

Local population
Benefitting from research; simplified institutions; search for sustainability

Research in green energy and efficient water use; calculation of Natural Protected Area carrying capacity

Strengthening of traditional local identity; social cohesion
Too many roads that No more fragment the landscape

Big, powerful multinationals; no environmental concerns

Loses power to multinationals

Oriented to maximize agriculture production

Overwhelmed by the power of companies

Protagonists after climate change effects; empowerment and diversification of activities

Turn towards sustainability after the effects of climate change; emergency integrative plans

Increase in activity after the effects of climate change; construction of agriculture research centers; increase in social science research

Rootlessness due to identity loss; no cohesion; emigration; counterculture movements grow
Construction of a new identity to cope with the effects of climate change
Increase in public transportation and dismantling of some roads

High demand for new infrastructures for tourism ; scarce public transport
Strengthened traditional local identity; social cohesion; higher education and culture; more creativity
Small, local companies; cooperatives; search

for long-term benefits; more concern

Were not mentioned ENGO with great importance in the creation of Doñana's National Park; confronted with the most developmentalist sectors

Great institutional simplification;

sustainability is the first aim

Research on social ecological systems, green energy, and efficient water use

Multiple institutions coexisting in the area

Focus on biological sciences research; local people perceive them as disconnected with population and local needs

Elder people and those linked to agriculture tend to see the protected area as a threat to their interest; people linked to tourism see the protected area as an opportunity for development

\section{Scenario 4: Adaptive Doñana - Wet and Creative}

What if local institutions and people begin to work together for the sustainability of Doñana, and the wetland dynamics become the core of water management? (See Fig. 4d.)

In this scenario, Doñana is conceptualized as a social-ecological system where the wetlands and the whole watershed become the heart and focus of management. Some areas of transformed marshes are restored. Investments in sanitation and education increase in response to demands for a higher human well-being. Management becomes more participative, and links between research, management, and education are fostered. New technologies for efficient irrigation are adopted; public transport is promoted, as well as nature tourism, thereby favoring small, local companies. A landscape mosaic of sustainable use maintains biodiversity. 


\section{Characterizing the scenarios through the provision of ecosystem services and human well-being: looking for consensus}

Fig. 5 presents the provision of ecosystem services and human well-being indicators in the four scenarios, and Fig. 6 summarizes the ecosystem services provision and human well-being indicators in the four scenarios, showing the main drivers of change. The most favorable scenarios for ecosystem services and human well-being are Doñana-Global Knowledge and Adaptive Doñana - Wet and Creative. The least favorable are Doñana Trademark and Arid Doñana. The statistical analysis demonstrated a high correlation between ecosystem services provision and human well-being in the four scenarios (Pearson correlation test: $R^{2}=$ $0.979, p=0.021$ ). This shows that the positive scenarios in terms of ecosystem service provision were also positive in terms of human well-being. Under the Adaptive Doñana - Wet and Creative scenario, there are evident trade-offs that shall be addressed. Intensive agriculture and beach tourism are reduced to maintain regulating services, which highly increase under this scenario. Under the Doñana - Global Knowledge scenario, the development of clean technologies and technologies of information-which is reflected in the great increase of two ecosystem services, i.e., environmental education and science and research -allows the increase of agriculture production levels as well as beach tourism without risking regulating services. Although equal in total terms of ecosystem services provision, for human wellbeing, the Adaptive Doñana - Wet and Creative scenario was slightly better than the Doñana Global Knowledge scenario.

The contacting of stakeholders by email to choose their preferred scenario provided a lower rate of response than wanted ( $21 \%$ of participants, 11 votes out of 53), although the contact was made twice. This suggests the need for a different way to contact stakeholders, such as a combination of email and telephone, as was done for the invitations to the workshops. Although the number of respondents was low, the scenario chosen was the one that was freely created as the desired scenario by one of the four working groups, i.e., Adaptive Doñana - Wet and Creative (82\% of the votes) followed by Doñana - Global Knowledge (18\%).

\section{Backcasting: general recommendations for decision-making}

The results of the backcasting exercise offer a set of management recommendations for each of the four aspects chosen (water, biodiversity, agriculture, and tourism and mobility). Table 3 shows the strategic objectives, or goals to achieve, and the main recommendations-i.e., those proposed by a higher number of participants - for these aspects. The increase of education and professional training is one of the recommendations that is found in every aspect. The recommendations for the creation of a general plan or agreement, including the different interests, to coordinate the management of some of these aspects such as biodiversity and tourism shows the need for understanding and team work among the region's different interest groups.

\section{DISCUSSION}

\section{Water as the core for management, education, and coordinated plans}

Water appears as a central element in all scenarios and two of them show how to reach a sustainable use of water. In the Doñana - Global Knowledge scenario, the problem of water scarcity is solved by the development of cheap water desalination techniques. Another alternative, in the absence of these techniques, is to place water at the core of management, as happens under the Adaptive Doñana - Wet and Creative scenario, and to adopt ecological boundaries such as the whole catchment for management (see Saunders et al. 2002).

The four scenarios developed also show some of the main dangers that Doñana faces, and how society could adapt to them if they happened. The biggest danger might be the scarcity of water, which could affect every other aspect of the system, such as biodiversity and local population, perhaps bringing some species to extinction or inciting social conflicts, as happens under the Doñana Trademark scenario. But it also could affect agriculture, making it return to dry crop varieties; or it could affect tourism by decreasing the numbers of visitors, as happens under the Arid Doñana scenario. Conflicts created by a severe scarcity of water might be rough, and unless research brings solutions to these problems and society adapts to them, like what 
Fig. 5. Provision of ecosystem services and human well-being variables under each scenario, compared to the current situation (big increase $=2$; increase $=1$; constant $=0$; decrease $=-1$, large decrease $=-2$ ). Abbreviations: Pollination \& pests reg. = Pollination \& pests regulation; Sat. biodiversity $=$ Satisfaction for biodiversity; Env. Education = Environmental education.

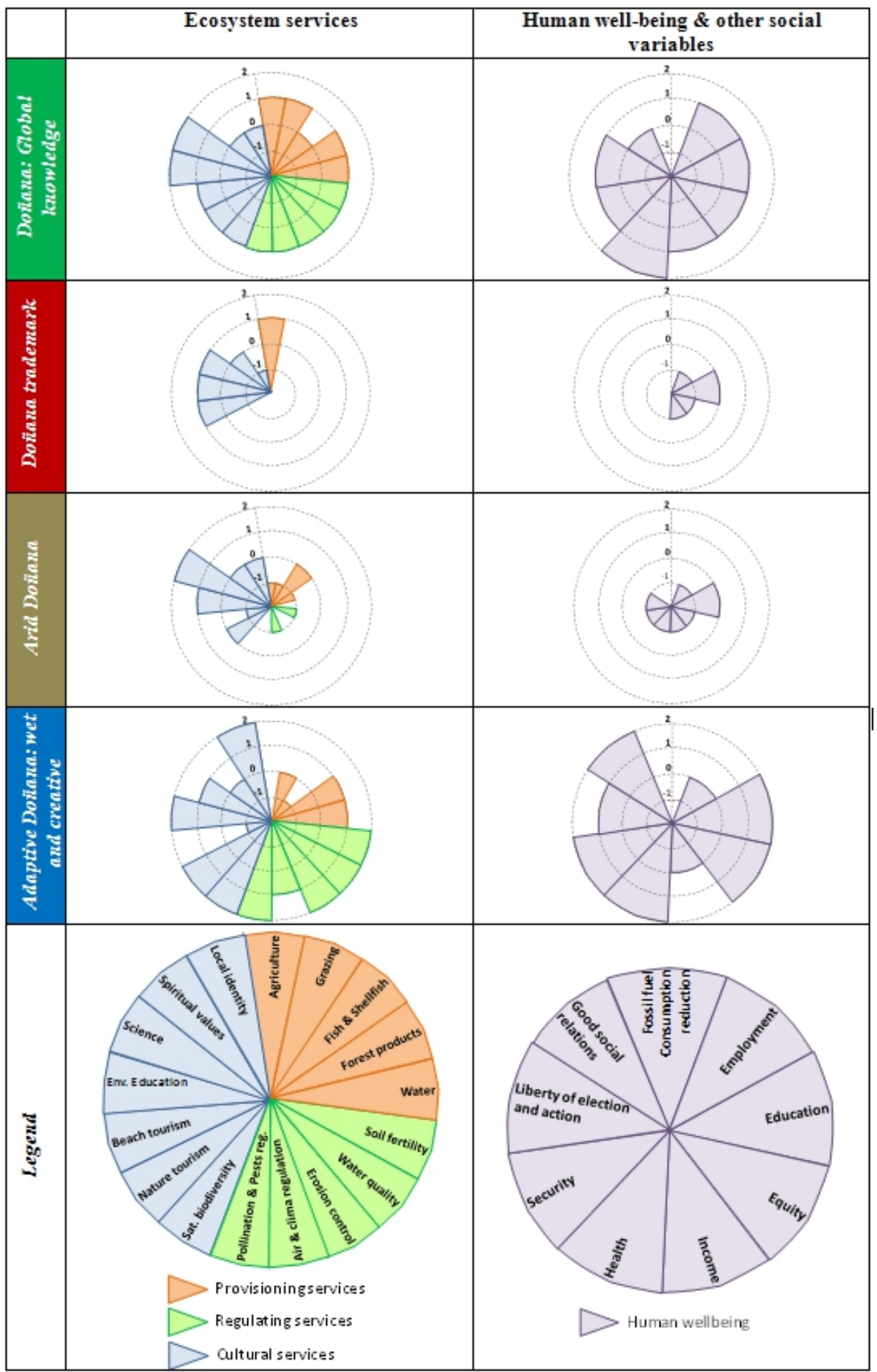


Fig. 6. Summary of the evolution of ecosystem services and human well-being under the four scenarios. The vertical axis refers to the management and the horizontal axis refers to the main drivers of change (in boxes).

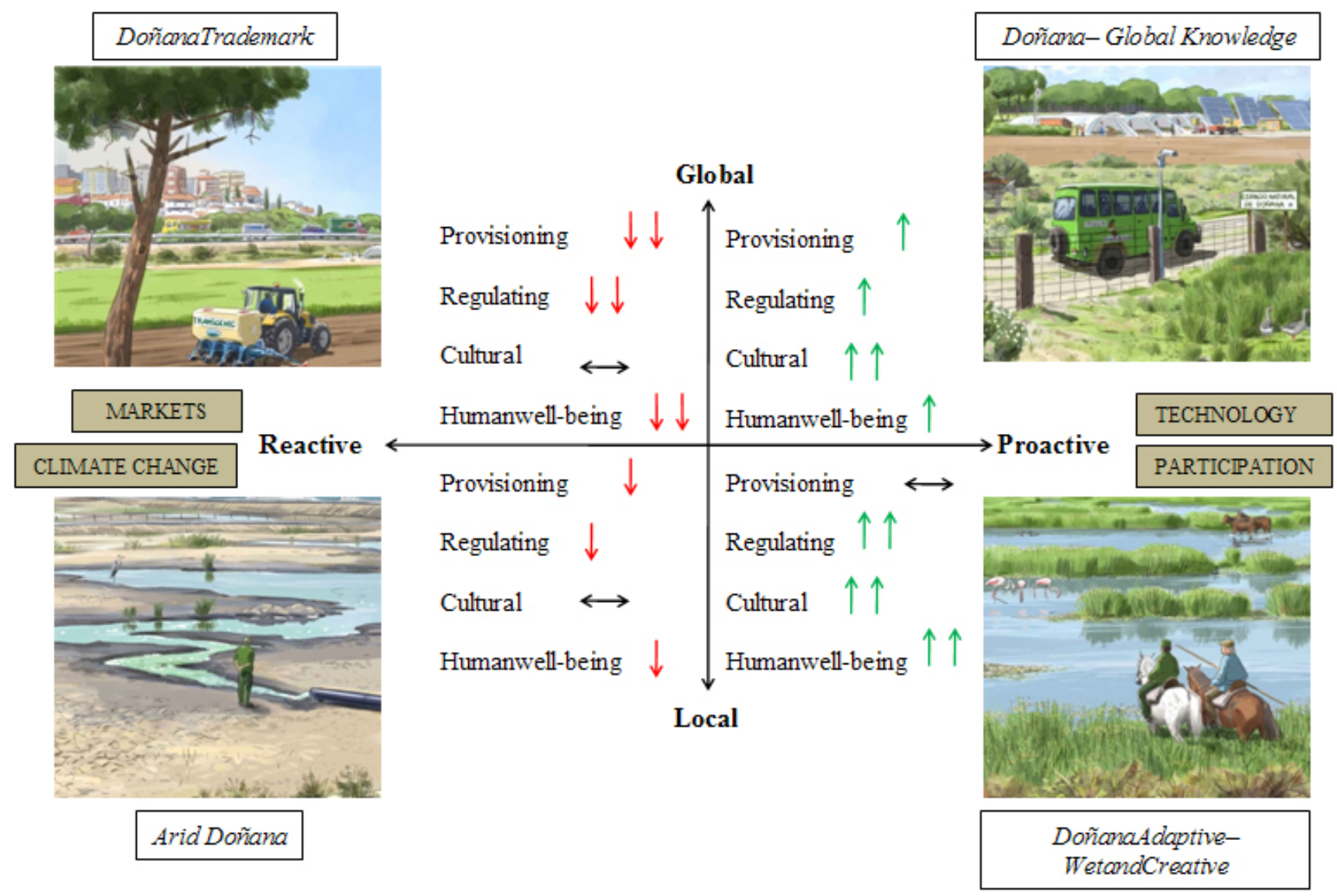

happens under the Arid Doñana scenario, a social crisis might emerge, as shown under the Doñana Trademark scenario.

Also, the four scenarios show what opportunities exist to improve ecosystem services and human well-being in Doñana. The two most positive scenarios in terms of ecosystem services and human well-being are the Adaptive Doñana - Wet and Creative or Doñana - Global Knowledge scenarios, in which environmental education is a crucial driver to increase awareness for conservation. Participatory processes under these scenarios also foster empowerment, dialogue among stakeholders from different groups of interest and the development of a shared sustainable future for Doñana.
Backcasting results might also help to close the gap between conservation and development. Education for sustainability and professional training is one of the main measures proposed and that could help that end, as well as the design of coordinated agreements or plans for the main aspects of the system. The general plan that now exists in Doñana for grazing, which regulates the amount of livestock that can live inside the protected area, is told by some stakeholders as an example of a general plan that should be reached for other aspects. Additionally, a coordinated decision-making process which incorporates sectoral policies, e.g., agriculture, tourism, conservation, etc., should be developed. 
Table 3. Strategic objectives and main management actions proposed for the Doñana social-ecological system, regarding the four aspects tackled through the backcasting approach.

\begin{tabular}{lll}
\hline \hline Aspect & Strategic objective & Main actions proposed \\
\hline Water & $\begin{array}{l}\text { Promote integrated river } \\
\text { basin management }\end{array}$ & $\begin{array}{l}\text { - Water shall be the core of management, conceptualizing the Donana } \\
\text { social-ecological system inside of its watershed } \\
\text { - It is essential to encourage education to raise awareness of local } \\
\text { education regarding sustainable water use }\end{array}$ \\
& $\begin{array}{l}\text { - Water-conserving technologies and initiatives, and nonirrigated crops, } \\
\text { shall be supported } \\
\text { - Re-naturalization and laws regarding water shall be enforced }\end{array}$
\end{tabular}

Biodiversity conservation

Agriculture mobility

\begin{abstract}
Achieve a general agreement for biodiversity, including the different interests
\end{abstract}

Achieve sustainable agriculture
- Education, participation, investigation, and communication shall be encouraged

- Measures of sustainability for all aspects that affect biodiversity, especially water, shall be adopted
- Local markets and quality labels shall be fostered, to reduce the number of intermediaries

- Training of professionals, encouragement of non-irrigated crops as well as ecological agriculture, and the implementation of new agroenvironmental measures are needed

- A general management plan for public transport shall be adopted - Tourism encouragement, professional's training, quality, and improvement of infrastructures shall be the main factors promoting tourism and mobility guidelines and promote quality and nature tourism

\section{Comparison of Doñana's scenarios and those of MedAction and Millennium Ecosystem Assessment}

A comparison of the MedAction and the Doñana scenarios shows some opportunities and challenges of the multi-scale scenario process. The comparison might be useful due to the very few examples of participatory scenario processes that have successfully integrated multiple scales (Biggs et al. 2007, Kok et al. 2007). The main drivers of the three Mediterranean MedAction scenarios (technology, market forces, and climate change) were quite accurately translated to the Doñana scenarios. This way, global drivers were incorporated to Doñana, avoiding the risk that local scenarios developed at a single scale have bias toward local driving forces and the risk of underestimating the external drivers also affecting the system (Enfors et al. 2008). The different drivers under each scenario gave them a positive or negative character. Market forces and climate change were main drivers of two negative scenarios, i.e., Doñana Trademark and Arid Doñana, while technologies and education produced a positive scenario, i.e., Doñana - Global Knowledge. Although the drivers conditioned the characteristics of the scenarios, there was a wide margin for creativity by the focus group participants, especially in the way that society could react to the circumstances generated by the drivers. Under Doñana Trademark, the reaction against the empowerment of large companies comes from a counterculture movement, but under the Arid Doñana scenario, society as a whole reacts to cope with climate change and reduce its impacts.

Nevertheless, some components of the MedAction scenarios were not adequately translated to Doñana. For example, the social division between connected and unconnected to the new technologies of the 
Knowledge is King scenario did not translate to Doñana because the working group believed that it did not apply to Doñana. Although unlikely, perhaps it would have been interesting to see how this social division would be in Doñana, but the facilitator did not persuade the group to address this issue. Because of that, it is important that facilitators and researchers agree, before the translation of the scenarios from one scale to another, which issues from the given scenarios should be addressed in the creation of the new scenarios. There still exists one uncertainty in this scenario, which refers to what will happen with immigration, because if population rises much, this could make sustainability more difficult to achieve and it could also make other people migrate.

For the Big is Beautiful scenario, the main drivers (market forces, loss of cultural identity and division in society between poor and rich), as well as some results (such as an increase in crime), were very accurately translated to Doñana. However, other results of the Big is Beautiful scenario, such as fortified cities or an increase in fires, were not translated to Doñana; others, such as the collapse of agriculture, were translated with some changes, which under the Doñana Trademark scenario resulted in the creation of kitchen gardens for subsistence. This shows how the drivers and main results of the given scenarios are easily translated to the new scenarios, but some outcomes of the given scenarios might be omitted or changed due to the soft degree of linkage chosen for the multi-scale scenarios, which, on the other hand, allowed a higher creativity.

For the Convulsive Change scenario, the main drivers (climate change and droughts), as well as the main scenario outcomes (reduction in irrigation, tourism decrease, migrations, and a change in general attitude towards a more sustainable way of living), were completely translated to the Arid Doñana scenario.

It is interesting to note that there are similarities between the Doñana scenarios and the global Millennium Ecosystem Assessment scenarios (see Cork et al. 2005). The similarities between the outcomes of the Millennium Ecosystem Assessment and the Doñana scenarios show that when the drivers are the same, the scenario outcomes might be similar. The Millennium Ecosystem Assessment TechnoGarden scenario is quite similar to DoñanaGlobal Knowledge, which might be a sort of "technological optimism" because technology is seen as a proactive solution for most environmental problems. Some characteristics of the Millennium Ecosystem Assessment's Order from Strength scenario, such as social division and a vision of the environment as something secondary, are reflected in the Doñana Trademark scenario. However, the greatest similarities exist between the Adapting Mosaic and Adaptive Doñana - Wet and Creative, as seen in Table 4. Social learning and local adaptive management are aspects that both scenarios share. Like the Adaptive Mosaic from the Millennium Ecosystem Assessment scenarios, Adaptive Doñana - Wet and Creative results in a multifunctional landscape that does not harm biodiversity and permits the transmission of traditional ecological knowledge, and where the importance of local institutions increases. Both scenarios could maintain both biological and cultural diversity if the drivers that damage them are controlled (see Pretty et al. 2009).

\section{What has been learned from the participatory scenario planning process?}

Through participatory scenario planning, stakeholders can understand trade-offs among ecosystem services and build an ecosystem services-oriented management strategy (Rodriguez et al. 2006, Bennett et al. 2009). The acknowledgement of these trade-offs permits the understanding of some of the adverse effects of the conflict between conservation and development, and can increase local people's incentives for conservation; this is especially true when the increase in provisioning services produces a decrease in regulating services. In the Doñana social-ecological system, the fact that water is a scarce resource - and that it is a critical aspect under great demand, as shown in the characterization of the present-is one of the effects of the conflict between conservation and development. This conflict is illustrated as a trade-off between agriculture and regulating services in the Adaptive Doñana - Wet and Creative scenario, in which agriculture largely decreases in quantity and regulating services grow, and they do so more than in any other scenario (Fig. 5).

Another important fact about scenarios is that they are not static snapshots of future events, but rather include a logical sequence of images of the future and drivers of change (Rotmans 2000). For the 
Table 4. Descriptions of Millennium Ecosystem Assessment's Adapting Mosaic scenario (Cork et al. 2005) and the Adaptive Doñana - Wet and Creative scenario.

\begin{tabular}{|c|c|}
\hline Millennium Ecosystem Assessment scenarios & Doñana scenario \\
\hline $\begin{array}{l}\text { The Adapting Mosaic scenario depicts a fragmented world } \\
\text { resulting from discredited global institutions. This scenario } \\
\text { sees the rise of local ecosystem-management strategies and the } \\
\text { strengthening of local institutions. Investments in human and } \\
\text { social capital are geared toward improving knowledge about } \\
\text { ecosystem functioning and management, thus resulting in a } \\
\text { better understanding of the importance of resilience, fragility, } \\
\text { and the local flexibility of ecosystems. Traditional knowledge } \\
\text { is maintained, with success for some uses. }\end{array}$ & $\begin{array}{l}\text { In the Adaptive Doñana - Wet and Creative scenario, } \\
\text { Doñana is conceptualized like a social-ecological system } \\
\text { where the wetlands and watershed become the heart of } \\
\text { management. Management becomes more participative, } \\
\text { and education and sustainability become the priorities of } \\
\text { society. The landscape mosaic permits the maintenance of } \\
\text { traditional uses and traditional ecological knowledge, } \\
\text { which coexist with modern knowledge and innovations. } \\
\text { The provision of regulating services will increase at the } \\
\text { expense of provisioning ecosystem services. }\end{array}$ \\
\hline
\end{tabular}

scenario development it might be useful to ask participants to divide scenarios in different time intervals (see Kok and Rothman 2003, Cork et al. 2005), which can help to create this sequence of images, especially if the scenarios are long (35 to 50 years). In the Doñana Trademark and Arid Doñana scenarios, this evolution in time is quite clear due to a need to overcome the negative initial conditions. In the Doñana - Global Knowledge and the Adaptive Doñana - Wet and Creative scenarios, the positive drivers produce many changes in time; even in the Doñana - Global Knowledge scenario, immigration rises at the end of the scenario due to the good environmental and social conditions, but changes during the scenario are not so disruptive. Fig. 2 of the Appendix shows flow diagrams of the scenarios where this evolution in time is more clear.

Although it is unusual for similar studies to conduct a vote among participants for their preferred scenarios, one study used this method to determine the preferred future land-use scenario (Fidalgo and Pinto 2005). The Adaptive Doñana - Wet and Creative scenario was created as the best possible evolution of Doñana and received the most votes. At times during the creation of the Adaptive Doñana - Wet and Creative scenario, participants felt that they were describing a utopian path towards the future. Although this might be true for some of the scenario outcomes, for others it could be realistic, and moreover, desired outcomes of the scenario were very useful for the backcasting approach that followed.
Although the backcasting approach has been used with few scenario processes, we think, as other authors do (Robinson 2003), that both approaches constitute a happy marriage for several reasons. While scenarios help to address uncertainty and show possible outcomes for certain drivers of change, the backcasting approach helps thinking about which management strategies, broad or concrete, should be adopted to avoid an undesirable scenario or to achieve a desired one. As all participants proposed management options, recommendations came from people belonging to different sectors such as agriculture, grazing, protected area management, research, or ENGO. Because of that, measures were proposed by stakeholders with a great knowledge of their own sector, avoiding problems that could happen when an external policy maker with a general knowledge decides what shall be done for managing a certain region. This bottom-up decision system also helps the empowerment of stakeholders regarding these strategies.

There is a need for a partnership between people and protected areas (McNeely 1994). In this sense, participation is a key strategy to engage local people and to link scientific and local knowledge about the management of the protected areas (Elbersen and Prados 1999). One successful example of the engagement of local people in the management of the protected areas is the fact that some of the protected areas guides are sons of ancient guards of the National Park, who show great interest and concern for the Doñana social-ecological system. 
This engagement in the management of protected areas could also help to build a common identity for the inhabitants of the socioeconomic area of influence of the Doñana protected areas, which could be a key issue in reaching sustainability. As this identity does not yet exist (Escalera 2007), the relationships among the 12 municipalities of the Doñana social-ecological system are problematic because the municipalities compete for scarce natural resources (e.g., water) and limited economic budgets.

\section{Future directions for protected areas}

Conservation and development can be reconciled if development becomes sustainable and if the needs of humans and nature are brought together to the conservation and development discourse (Hammer 2007). The exclusion of local people from the management of protected areas due to top-down approaches might lead to the conservation vs. development model, and thus to social conflict for using key ecosystem services, such as water and threats to biodiversity inside the protected areas. That confrontation occurs due to protected areas shows that, although protected areas shall be designed and managed to provide benefits to society (Holdgate 1994, McNeely 1994), they are not understood in that sense. Moreover, and as noted before for Doñana (Ojeda-Rivera 1986), we are facing a false dilemma. Protection and development should find interests in common instead of generating opposed paths.

The participatory scenario planning approach under the ecosystem services framework has contributed to developing a vision of the future sustainability of the Doñana social-ecological system - the Adaptive Doñana - Wet and Creative scenario-and to proposing guidelines to achieve it. Among the protected area categories of the International Union for Conservation of Nature (IUCN), the fifth category fits best to this scenario and could be appropriate in other social-ecological systems in which protected areas are embedded. This category of reserve describes the following (Philips 2002):

Area of land, with coast and sea as appropriate, where the interaction of people and nature over time has produced an area of distinct character with significant aesthetic, ecological and/or cultural value, and often with high biological diversity. Safeguarding the integrity of this traditional interaction is vital to the protection, maintenance and evolution of such an area.

This category might avoid some of the problems of the use-restrictive conservation normative that national parks have traditionally implemented. Consistent with this category, the Doñana National Park is slowly becoming a multi-functional protected area (see Holdgate 1994) because some traditional uses are now being allowed under regulation, after having experienced a period of prohibition.

However, if some traditional uses are allowed inside the protected areas, the outlying areas might be managed in ways that do not harm the lands within protected areas. As human land-use activities in the surrounding matrix affect the lands within the protected areas, the success of protected areas depends on managing the entire landscape (Wiens 1996).

The need to expand conservation beyond the limits of protected areas is recognized in the literature (Bennett 1994, Holdgate 1994, International Union for Conservation of Nature 2004, deFries et al. 2005). Landscape planning is regarded as the basic tool for organizing nature conservation outside protected areas (Sepp et al. 1999, Bengtsson et al. 2003), and landscape conservation has been called the new paradigm for the conservation of biodiversity (With 2005). Designing a landscape where certain uses can coexist with biodiversity conservation and protected areas should be the first aim for landscape planning in places such as the Doñana social-ecological system. For example, surrounding lands of protected areas where agriculture is the main economic activity, could be converted to ecoagriculture landscapes (Scherr and McNeely 2008). Moreover, instead of isolated or static reserves, dynamic reserves in space and time where resilience as well as ecological memory are maintained outside the protected areas' boundaries are needed for long-term biodiversity conservation (Bengtsson et al. 2003). Multiple dynamic boundaries of protected areas could help to reach these aims (Zimmerer 2000).

Because people cannot be separated from nature, we must move from a way of thinking in which conservation is pitted against development to a framework of conservation for development (Folke 
2006). In European multi-functional landscapes, traditional cultural practices can maintain a range of economic, social, and ecosystem services (Jones Walters 2008). Biodiversity, a range of ecosystem services and economic incentives should coexist if our aim is to promote human well-being. The fifth category of reserves of the International Union for Conservation of Nature might be a suitable strategy for the protected areas in the semi-natural Mediterranean systems.

Responses to this article can be read online at: http://www.ecologyandsociety.org/voll6/iss1/art23/ responses/

\section{Acknowledgments:}

The authors wish to thank all the people who collaborated on this project, especially those who were surveyed or interviewed or who participated in the workshops. We also thank Jesús Mateos for sharing his knowledge about the Doñana socialecological system and Diana Calvo, Marina García, Irene Iniesta, Elisa Oteros, and Concepción Piñeiro for their help during the workshops. We are also thankful to two anonymous reviewers for comments on early drafts of this paper. Funding for development of this project was provided by the World Wildlife Fund-Spain and by the Autonomous Organization of National Parks, Ministry of the Environment and Rural and Marine Affairs (018/2009).

\section{LITERATURE CITED}

Aguilar Fernández, S. 2008. The legitimacy problems in Spanish nature policy: The case of Doñana. Pages 83-100 in J. Keulartz and G. Leistra, editors. Legitimacy in European nature conservation policy: case studies in multilevel governance. Springer, New York, New York, USA.

Anderies, J. M., M. A. Janssen, and E. Ostrom. 2004. A framework to analyze the robustness of socialecological systems from an institutional perspective. Conservation Ecology 9(1):18. [online] URL: http: //www.ecologyandsociety.org/vol9/iss1/art18.
Andersen, I. E., and B. Jaeger. 1999. Scenario workshops and consensus conferences: towards more democratic decision-making. Science and Public Policy 26(5):331-340.

Atienza-Serna, L. 2001. Desarrollo sostenible y medio ambiente. Pages 157-166 in C. Roman del Río, editor. Aprendiendo a Innovar: Regiones del conocimiento. Instituto de desarrollo regional, Fundación Interuniversitaria.

Atienza-Serna, L., M. González Ruiz, and A. Villa Díaz. 2003. Bases estratégicas para una agricultura sostenible en Doñana. De la agricultura al desarrollo rural sostenible. Fundación Doñana 21, Huelva, Spain.

Baker, J. P., D. W. Hulse, S. V. Gregory, D. White, J. Van Sickle, P. A. Berger, D. Dole, and N. H. Schumaker. 2004. Alternative futures for the Willamette River Basin, Oregon. Ecological Applications 14(2):313-324.

Bengtsson, J., P. Angelstam, T. Elmqvist, U. Emanuelsson, C. Folke, M. Ihse, F. Moberg, and M. Nyström. 2003. Reserves, resilience and dynamic landscapes. Ambio 32(6):389-396.

Bennett, E.M., G. D. Peterson, and L. J. Gordon. 2009. Understanding relationships among multiple ecosystem services. Ecology Letters 12:1394-1404.

Bennett, G., editor. 1994. Conserving Europe's natural heritage: towards a European ecological network. In Conserving Europe's natural heritage: towards a European ecological network; proceedings of the international conference held in Maastricht, 9-12 November 1993. Graham \& Trotman:Martinus Nijhoff, London, UK.

Berkes, F., and I. J. Davidson-Hunt. 2006. Biodiversity, traditional management systems, and cultural landscapes: examples from the boreal forest of Canada. International Social Science Journal 187:35-47.

Berkes, F., and C. Folke. 1998. Linking social and ecological systems: management practices and social mechanisms for building resilience. Cambridge University Press, Cambridge, UK.

Biggs, R., C. Raudsepp-Hearne, C. AtkinsonPalombo, E. Bohensky, E. Boyd, G. Cundill, H. Fox, 
S. Ingram, K. Kok, S. Spehat, M. Tengö, D. Timmer, and M. Zurek. 2007. Linking futures across scales: a dialogue on multiscale scenarios. Ecology \& Society 12(1): 17. [online] URL: http://www.ecolog yandsociety.org/vol12/iss1/art17/.

Bohensky, E. L., B. Reyers, and A. S. Van Jaarsveld. 2006. Future ecosystem services in a Southern African river basin: a scenario planning approach to uncertainty. Conservation Biology 20(4):1051-1061.

Brown K., W. N. Adger, E. Tomkins, P. Bacon, D. Shim, and K. Young. 2001. Trade-off analysis for marine protected area management. Ecological Economics 37:417-434.

Butler, C. D., R. Chambers, K. Chopra, P. Dasgupta, A. Duraiappah, P. Kumar, A. J. McMichael, and N Wen-Yuan N. 2003. Ecosystems and human wellbeing. Pages 71-84 in Ecosystems and human wellbeing: a framework for assessment. Millennium Ecosystem Assessment, and Island Press, Washington, D.C., USA.

Carlson-Kanyama A., K. Henrik Dreborg, H. C. Moll, and D. Padovan. 2008. Participative backcasting: a tool for involving stakeholders in local sustainability planning. Futures 40:34-46.

Carmona, J., and F. Fuentelsaz. 2006. Problemas Ambientales de la Comarca de Doñana. Situación actual y propuestas. World Wildlife Fund, Madrid, Spain.

Carpenter, S. R., E. M. Bennett, and G. D. Peterson. 2006. Scenarios for ecosystem services: an overview. Ecology \& Society 11(1): 29. [online] URL: http://www.ecologyandsociety.org/vol11/iss1/ $\underline{\operatorname{art} 29 /}$.

Carpenter, S. R., P. L. Pingali, E. Bennett, and M. Zurek, editors. 2005. 2005. Ecosystems and human well-being: scenarios. Millennium Ecosystem Assessment, and Island Press, Washington, D.C., USA.

Cork, S., G. Peterson, G. Petschel-Held, J. Alcamo, J. Alder, E. M. Bennett, E. R. Carr, D. Deane, G. C. Nelson, T. Ribeiro, C. Butler, E. M. Mendiondo, W. Olouch-Kosura, and M. Zurek. 2005. Four scenarios. Pages 223-294 in S. R. Carpenter, P. L. Pingali, E. Bennett, and M. Zurek, editors. Ecosystems and human well-being: scenarios.
Millennium Ecosystem Assessment, and Island Press, Washington, D.C., USA.

Corominas, J. 1995. La agricultura en el entorno de Doñana. Revista de Obras Públicas 3340:65-74.

Defries, R., A. Hansen, A. C. Newton, and M. C. Hansen. 2005. Increasing isolation of protected areas in tropical forest over the past twenty years. Ecological Applications 15(1):19-26.

de Groot, R. 2006. Function-analysis and valuation as a tool to assess land use conflicts in planning for sustainable, multi-functional landscapes. Landscape and Urban Planning 75:175-186.

de Groot, R., M. Stuip, M. Finlayson, and N. Davidson. 2006. Valuing wetlands: guidance for valuing the benefits derived from wetland ecosystem services. Ramsar Technical Report No. 3, CBD Technical Series No. 27. Ramsar Convention Secretariat, Gland, Switzerland.

Doctor, A. M. 2009. Rural tourism and urban growth regulations in Doñana National Park: antecedents and current planning. Pages 109-123 in M. J. Prados, editor. Naturbanization: new identities and processes for rural-natural areas. Taylor \& Francis Group, London, UK.

Dreborg, K. H. 1996. Essence of backcasting. Futures 28(9):813-828.

Elbersen, B. 2001. Nature on the doorstep: the relationship between protected natural areas and residential activity in the European countryside. Alterra, Utrecht/Wageningen, The Netherlands.

Elbersen, B., and M. J. Prados. 1999. Desarrollo rural y calidad de vida en el entorno del Parque Nacional de Doñana. Revista de estudios Regionales 55:47-76.

Elster, J., editor. 1998. Deliberative democracy. Cambridge University Press, Cambridge, UK.

Enfors, E. I., L. J. Gordon, G. D. Peterson, and D. Bossio. 2008. Making investments in dryland development work: participatory scenario planning in the Makanya catchment, Tanzania. Ecology \& Society 13(2): 42. [online] URL: http://www.ecolog yandsociety.org/vol13/iss2/art42/ . 
Escalera, J. 2007. Cohesión y participación social en Doñana: Propuestas para el debate, Universidad Pablo de Olavide. Document from the participative process of the II Sustainable Development Plan, Seville, Spain.

Fernández, M., and F. Borja-Barrera. 2006. Doñana y cambio climático: Propuestas para la mitigación de los efectos. World Wildlife Fund, Madrid, Spain.

Fernández-Delgado, C. 1997. Conservation management of a European natural area: Doñana National Park, Spain. Pages 458-467 in G. K. Meffe and C. R. Carroll, editors. Principles of conservation biology. Sinauer Associates, Sunderland, Massachusetts, USA.

Fidalgo, B., and L. M. Pinto. 2005. Linking landscape functions and preferences in forest landscapes - a tool for scenario building and evaluation: a contribution from the VisuLands Project. Pages 34-35 in E. Lange and D. Miller, editors. Proceedings of our shared landscape: integrating ecological socio-economic and aesthetic aspects in landscape planning and management. Ascona, Switzerland.

Folke, C. 2006. The economic perspective: conservation against development versus conservation for development. Conservation Biology 20 (3):686-688.

Gómez-Baggethun, E. 2010. Ecologizar la economía o economizar la ecología. Controversias teóricas y desafíos prácticos en la valoración de los servicios de los ecosistemas. Thesis. Departamento de Ecología, Universidad Autónoma de Madrid, Madrid, Spain.

Gómez-Baggethun, E., S. Mingorría, V. ReyesGarcía, L. Calvet, and C. Montes. 2010. Traditional ecological knowledge trends in the transition to a market economy: empirical study in the Doñana natural areas. Conservation Biology, in press.

González-Arteaga, J. 1993. Las marismas del Guadalquivir: etapas de su aprovechamiento económico. Antonio Cuevas, editor. Seville, Spain.

Grimalt, J. O., M. Ferrer, and E. Macpherson. 1999. The mine tailing accident in Aznalcollar. The Science of the Total Environment 242:3-11.
Gude, P. H., A. J. Hansen, and D. A. Jones. 2007. Biodiversity consequences of alternative future land use scenarios in Greater Yellowstone. Ecological Applications 17(4):1004-1018.

Gunderson, L. H., C. S. Holling, and S. S. Light, editors. 1995. Barriers and bridges to the renewal of ecosystems and institutions. Columbia University Press, New York, New York, USA.

Hammer, T. 2007. Protected areas and regional development: conflicts and opportunities. Pages 21-36 in I. Mose, editor. Protected areas and regional development in Europe: towards a new model for the $21^{\text {st }}$ century. Ashgate Publishing Company, Hampshire, England.

Hansen, A. J., R. De Fries, and W. Turner. 2004. Land use change and biodiversity: a synthesis of rates and consequences during the period of satellite imagery. Pages 277-299 in G. Gutman and C. Justice, editors. Land change science: observing, monitoring, and understanding trajectories of change on the Earth's surface. Springer-Verlag, New York, USA.

Heimlich, R. E., K. D. Wiebe, R. Claassen, D. Gadsby, and R. M. House. 1998. Wetlands and agriculture: private interests and public benefits. Agricultural Economic Report No. 765. Resource Economics Division, Economic Research Service, U.S. Department of Agriculture.

Holdgate, M. W. 1994. Protected areas in the future: the implications of change, and the need for new policies. Biodiversity and Conservation 3:406-410.

Holling, C. S., and G. K. Meffe. 1996. Command and control and the pathology of natural resource management. Conservation Biology 10(2):328-337.

Huss, W. R. 1988. A move toward scenario analysis. International Journal of Forecasting 4:377-388.

International Union for Conservation of Nature (World Conservation Union). 2004. The Durban Action Plan: Vth IUCN World Parks Congress, Durban, South Africa. International Union for Conservation of Nature, Gland, Switzerland. 
Jessel, B., and J. Jacobs. 2005. Land use scenario development and stakeholder involvement as tools for watershed management within the Havel river basin. Limnologica 35:220-233.

Jones Walters, L. 2008. Biodiversity in multifunctional landscapes. Journal of Nature Conservation 16:117-119.

Kok, K., R. Biggs, and M. Zurek. 2007. Methods for developing multi-scale participatory scenarios: insights from Southern Africa and Europe. Ecology \& Society 13(1): 8. [online] URL: http://www.ecol ogyandsociety.org/vol12/iss1/art8/.

Kok, K., M. Patel, and D. S. Rothman. 2004. Final report of European and Mediterranean scenarios: upscaling the results from the target area scenarios. MedAction Deliverable 4. International Centre for Integrated Assessment and Sustainable Development (ICIS) Working Paper I04-E002. Maastricht University, Maastricht, The Netherlands.

Kok, K., and D. S. Rothman. 2003. Mediterranean scenarios. MedAction Deliverable 3. First Draft. Report number I03-E001. International Centre for Integrated Assessment and Sustainable Development (ICIS), Maastricht, The Netherlands.

Kok, K., D. S. Rothman, and M. Patel. 2006. Multiscale narratives from an IA perspective: Part I. European and Mediterranean scenario development. Futures 38:261-284.

Lanzarot Freudenthal, M. P. 2007. Cianobacterias tóxicas y mortandades en masa de fauna salvaje en las marismas de Doñana. Thesis. Universidad Complutense de Madrid, Madrid, Spain.

Ludwig, D. 2001. The era of management is over. Ecosystems 4:758-764.

Lynam T., W. de Jong, D. Sheil, T. Kusumanto, and K. Evans. 2007. A review of tools for incorporating community knowledge, preferences, and values into decision making in natural resources management. Ecology \& Society 12(1): 5. [online] URL: http://w ww.ecologyandsociety.org/vol12/iss1/art5/.

Martín-López, B., E. Gómez-Baggethun, P. L. Lomas, and C. Montes. 2009b. Effects of spatial and temporal scales on cultural services valuation. Journal of Environmental Management 90:1050-1059.
Martín-López, B., C. Montes, and J. Benayas. 2007a. Influence of user characteristics on valuation of ecosystem services in Doñana Natural Protected Areas (south-west Spain). Environmental Conservation 34(3):215-224.

Martín-López, B., C. Montes, L. Ramírez and J. Benayas. 2009a. What drives policy decisionmaking related to species conservation? Biological Conservation 142:1370-1380.

McNeely, J. A. 1994. Protected areas for the 21st century: working to provide benefits to society. Biodiversity and Conservation 3:390-405.

Méndez-Contreras, J., F. Dickinson, and T. Castillo Burguete. 2008. Community member viewpoints on the Ría Celestún Biosphere Reserve, Yucatan, Mexico: suggestions for improving the community/ natural protected area relationship. Human Ecology 36:111-123.

Montes, C., F. Borja, M. A. Bravo, and J. M. Moreira. 1998. Reconocimiento Biofísico de Espacios Naturales Protegidos. Doñana: Una Aproximación Ecosistómica. Consejería de Medio Ambiente, Junta de Andalucía, Sevilla, España.

Nakišenoviš, N., and 26 co-authors. 2000. Special report on emissions scenarios. Cambridge University Press, Cambridge, UK.

Narayan, D., R. Chambers, M. K. Shah, and P. Petesch. 1999. Global synthesis: consultations with the poor. World Bank, Washington, DC.

Naughton-Treves, L., M. Buck-Holland, K. Brandon. 2005. The role of protected areas in conserving biodiversity and sustaining local livelihoods. Annual Review of Environment and Resources 30:219-252.

Ojeda-Rivera, J. F. 1986. Protéction ou développment. La creation et l'abuse d'un faux dilemme relative au P.N. Doñana et de sa región. Pages 275-279 in L'Harmattan, editor. Du rural à l'environnement. XII Colloque National de l'Association des Ruralistes Français (A.R.F.), Paris, France.

Ojeda-Rivera, J. F. 1987. Organización del territorio en Doñana y su Entorno próximo 
(Almonte). Siglos XVIII-XX. Instituto para la Conservación de la Naturaleza, Ministerio de Agricultura, Pesca y Alimentación, Madrid, Spain.

Ojeda-Rivera, J. F. 1990. Doñana paisaje culturalDoñana cultural landscape. Pages 18-25 in Doñana: la naturaleza en España, (Edición bilingüe). Lundwerg, Barcelona, Spain.

Ojeda-Rivera, J. F. 1999. Espacios naturales protegidos y desarrollo sostenible. Pages 273-286 in Federación de espacios naturales protegidos de Andalucía: Asociación de Geógrafos Españoles. Geografía y espacios naturales protegidos, Sevilla, Spain.

Ojeda-Rivera, J. F., and L. Moral Ituarte. 2004. Percepciones del agua y modelos de su gestión en las distintas fases de la configuración de Doñana. Investigaciones Geográficas 35:25-44.

Oñate, J. J., D. Pereira, and F. Suárez. 2003. Strategic Environmental Assessment of the effects of European Union's Regional Development Plans in Doñana National Park (Spain). Environmental Management 31(5):642-655.

Pereira, E., C. Queiroz, H. M. Pereira, and L. Vicente. 2005. Ecosystem services and human wellbeing: a participatory study in a mountain community in Portugal. Ecology \& Society 10(2): 14. [online] URL: http://www.ecologyandsociety.org/ vol10/iss2/art14/.

Peterson, G. D., T. D. Beard Jr., B. E. Beisner, E. M. Bennett, S. R. Carpenter, G. S. Cumming, C. L. Dent, and T. D. Havlicek. 2003a. Assessing future ecosystem services: a case study of the Northern Highlands Lake District, Wisconsin. Conservation Ecology 7(3):1. [online] URL: http://www.consecol. org/vol7/iss3/art1/ .

Peterson, G. D., G. S. Cumming, and S. R. Carpenter. 2003b. Scenario planning: a tool for conservation in an uncertain world. Conservation Biology 17(2):358-366.

Philips, A. 2002. Management Guidelines for IUCN Category V Protected Areas: Protected Landscapes/ Seascapes. International Union for Conservation of Nature, Gland, Switzerland and Cambridge, UK.

Phillips, A. 2003. Turning ideas on their head: the new paradigm for protected areas. The George Wright Forum 20(2):8-32.
Pimbert, M. P., and J. N. Pretty. 1997. Parks, people and professionals: putting "participation" into protected-area management. Pages 297-332 in K. B. Ghimire and M. P. Pimbert, editors. Social change and conservation: environmental politics and impacts of national parks and protected areas. Earthscan, London, UK.

Pretty, J. 2003. Social capital and the collective management of resources. Science 302:1912-1914.

Pretty, J., and 14 co-authors. 2009. The intersections of biological diversity and cultural diversity: towards integration. Conservation and Society 7(2):100-112.

Reed, M. S. 2008. Stakeholder participation for environmental management: a literature review. Biological Conservation 141:2417-2431.

Reed, M. S., A. Graves, N. Dandy, H. Posthumus, K. Hubacek, J. Morris, C. Prell, C. H. Quinn, and L. C. Stringer. 2009. Who's in and why? A typology of stakeholder analysis methods for natural resource management. Journal of Environmental Management 90:1933-1949.

Ribot, J. C. 2002. Democratic decentralization of natural resources: institutionalizing popular participation. World Resources Institute, Washington, D.C., USA.

Rist, S., M. Chidambaranathanb, C. Escobarc, U. Wiesmannd, and A. Zimmermanne. 2007. Moving from sustainable management to sustainable governance of natural resources: the role of social learning processes in rural India, Bolivia and Mali. Journal of Rural Studies 23(1):23-37.

Robinson, J. 2003.Future subjunctive: backcasting as social learning. Futures 35:839-856.

Rodríguez, J. P., T. D. Beard, Jr., E. M. Bennett, G. S. Cumming, S. Cork, J. Agard, A. P. Dobson, and G. D. Peterson. 2006. Trade-offs across space, time, and ecosystem services. Ecology \& Society 11(1): 28. [online] URL: http://www.ecologyandsociety.org/ vol11/iss1/art28/.

Rotmans, J., M. van Asselt, C. Anastasi, S. Greeuw, J. Mellors, S. Peters, D. Rothman, and N. Rijkens. 2000. Visions for a sustainable Europe. Futures 32:809-831. 
Roux, D. J., K. H. Rogers, H. C. Biggs, P. J. Ashton, and A. Sergeant. 2006. Bridging the sciencemanagement divide: moving from unidirectional knowledge transfer to knowledge interfacing and sharing. Ecology \& Society 11(1): 4. [online] URL: http://www.ecologyandsociety.org/vol11/iss1/art4/

Ruiz, F., A. Rodríguez-Ramírez, L. M. Cáceres, J. Rodríguez Vidal, M. Isabel Carretero, M. Abad, M. Olías, and M. Pozo. 2005. Evidence of high-energy events in the geological record: Mid-holocene evolution of the southwestern Doñana National Park (SW Spain). Palaeogeography, Palaeoclimatology, Palaeoecology 229:212-229.

Sala, O. E., and 18 co-authors. 2000. Global biodiversity scenarios for the year 2100. Science 287:1770-1774.

Sandker, M., A. Suwarno, and B. M. Campbell. 2007. Will forests remain in the face of oil palm expansion? Simulating change in Malinau, Indonesia. Ecology \& Society 12(2):37. [online] URL: http://www.ecologyandsociety.org/vol12/iss2/ art37/.

Saunders, D. L., J. J. Meeuwig, and A. C. J. Vincent. 2002. Freshwater protected areas: strategies for conservation. Conservation Biology 16(1):30-41.

Scherr, S. J., and J. A. McNeely. 2008. Biodiversity conservation and agricultural sustainability: towards a new paradigm of "ecoagriculture" landscapes. Philosophical Transactions of the Royal Society B 363:477-494.

Sepp, K., H. Palang, U. Mander, and A. Kaasik. 1999. Prospects for nature and landscape protection in Estonia. Landscape and Urban Planning 46:161-167.

Stringer, L.C., A. J. Dougill, E. Fraser, K. Hubacek, C. Prell, and M. S. Reed. 2006. Unpacking "participation" in the adaptive management of social-ecological systems: a critical review. Ecology \& Society 11(2):39. [online] URL: (http:// www.ecologyandsociety.org/vol11/iss2/art39/ ).

Svancara, L. K, J. M. Scott, T. R. Loveland, and A. B. Pidgorna. 2009. Assessing the landscape context and conversion risk of protected areas using satellite data products. Remote Sensing of Environment 113:1357-1369.
Tippett, J., J. F. Handley, and J. Ravetz. 2007. Meeting the challenges of sustainable development - a conceptual appraisal of a new methodology for participatory ecological planning. Progress in Planning 67:9-98.

Tompkins, E. L., R. Few, and K. Brown. 2008. Scenario-based stakeholder engagement: incorporating stakeholders preferences into coastal planning for climate change. Journal of Environmental Management 88:1580-1592.

Van der Zouwen, M. 2006. Dynamics in nature policy practices across the European union. Pages 139-159 in B. Arts and P. Leroy, editors. Dynamics in nature policy practices across the European Union. Springer, Dordrecht, Holland.

Warner, M. 1997. "Consensus" participation: an example for protected areas planning. Public Administration and Development 17:413-432.

Weber, J. L. et al. 2008. Ecosystem accounting for the cost of biodiversity losses: framework and case study for coastal Mediterranean wetlands, 31 March 2008. European Environment Agency, Copenhagen, Denmark. [online] URL: http://www.eea.europa.eu/ highlights/understanding-the-full-value-of-biodiversityloss/ecosystem-accounting-for-the-cost-of-biodiversitylosses-framework-and-case-study-for-coastalmediterranean-wetlands-abstract-2013-31-march-2008

West, P., J. Igoe, and D. Brockington. 2006. Parks and peoples: the social impact of protected areas. Annual Review of Anthropology 35:251-277.

Wiens, J. A. 1996. Wildlife in patchy environments: metapopulations, mosaics, and management. Pages 53-84 in D. R. McCollough, editor. Metapopulations and conservation. Island Press, Covelo, California, USA.

With, K. A. 2005. Landscape conservation: a new paradigm for the conservation of biodiversity. Pages 238-247 in J. Wiens and M. Moss, editors. Issues and perspectives in landscape ecology. Cambridge University Press, Cambridge, UK.

Wollenberg, E., D. Edmunds, and L. Buck. 2000. Using scenarios to make decisions about the future: anticipatory learning for the adaptive comanagement of community forests. Landscape and Urban Planning 47:65-77. 
Zimmerer, K. S. 2000. The reworking of conservation geographies: nonequilibrium landscapes and nature-society hybrids. Annals of the Association of American Geographers 90 (2):356-369.

Zurek, M. B., and T. Henrichs. 2007. Linking scenarios across geographical scales in international environmental assessments. Technological Forecasting \& Social Change 74:1282-1295. 
Fig. 1. Diagram of the backasting poster. The description of the characteristics of the aspects chosen (water, biodiversity, agriculture, and tourism and mobility) in the present and their description in the future scenarios were prepared by the research team before the second workshop using the first workshop outputs. Participants wrote management strategies on their cards for the short and medium term that would lead to a desirable future or avoid an undesirable one.

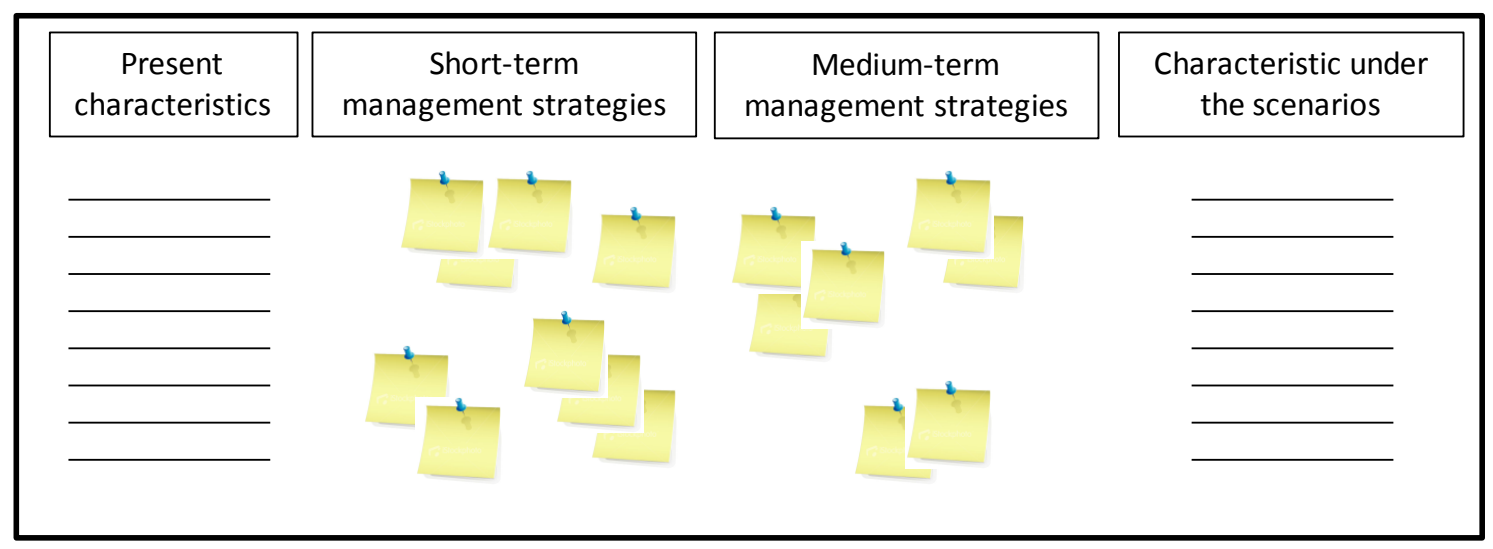

Fig. 2. Flux-diagrams of interactions of the 4 scenarios. Drivers of change are illustrated in shaded square boxes, actors (stakeholder groups) in violet ellipses, aspects (main components of the system) in white ellipses, factors (sub-components of the system) in green ellipses and results or responses in white square boxes. The arrow colors indicate cause, a positive effect, negative effect or indeterminate effect.

\section{DOÑANA: GLOBAL KNOWLEDGE}

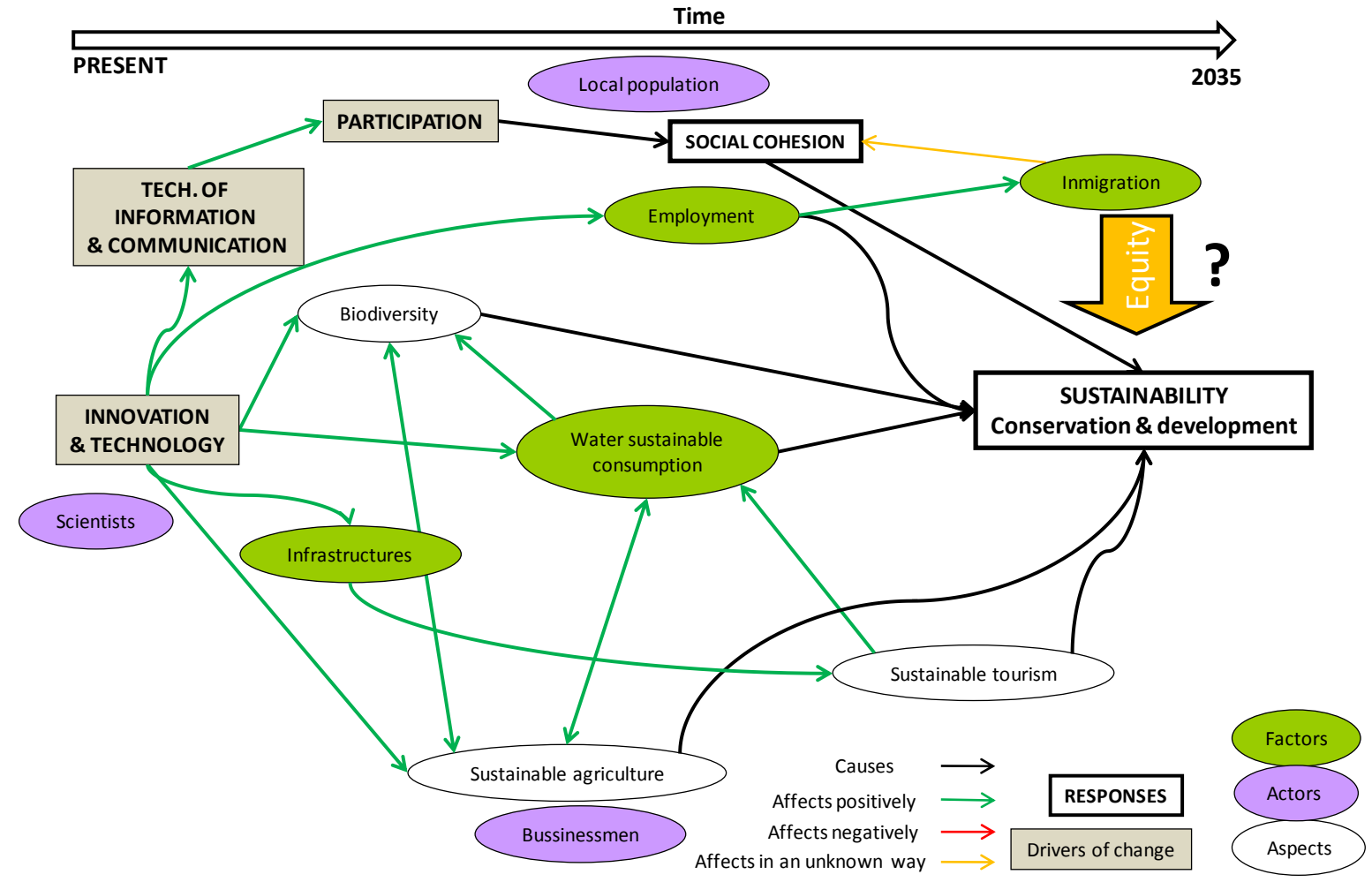




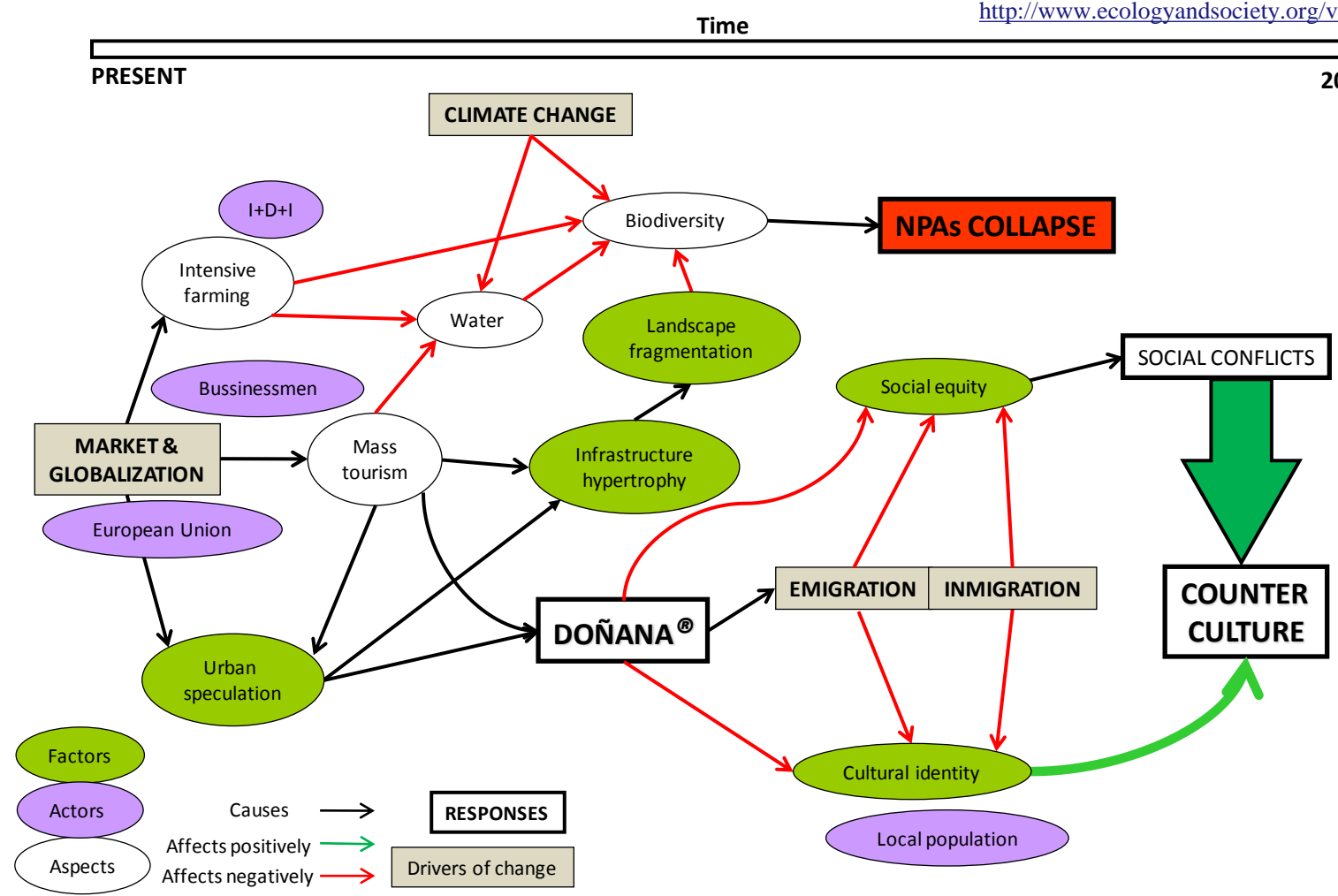

\section{ARID DOÑANA}

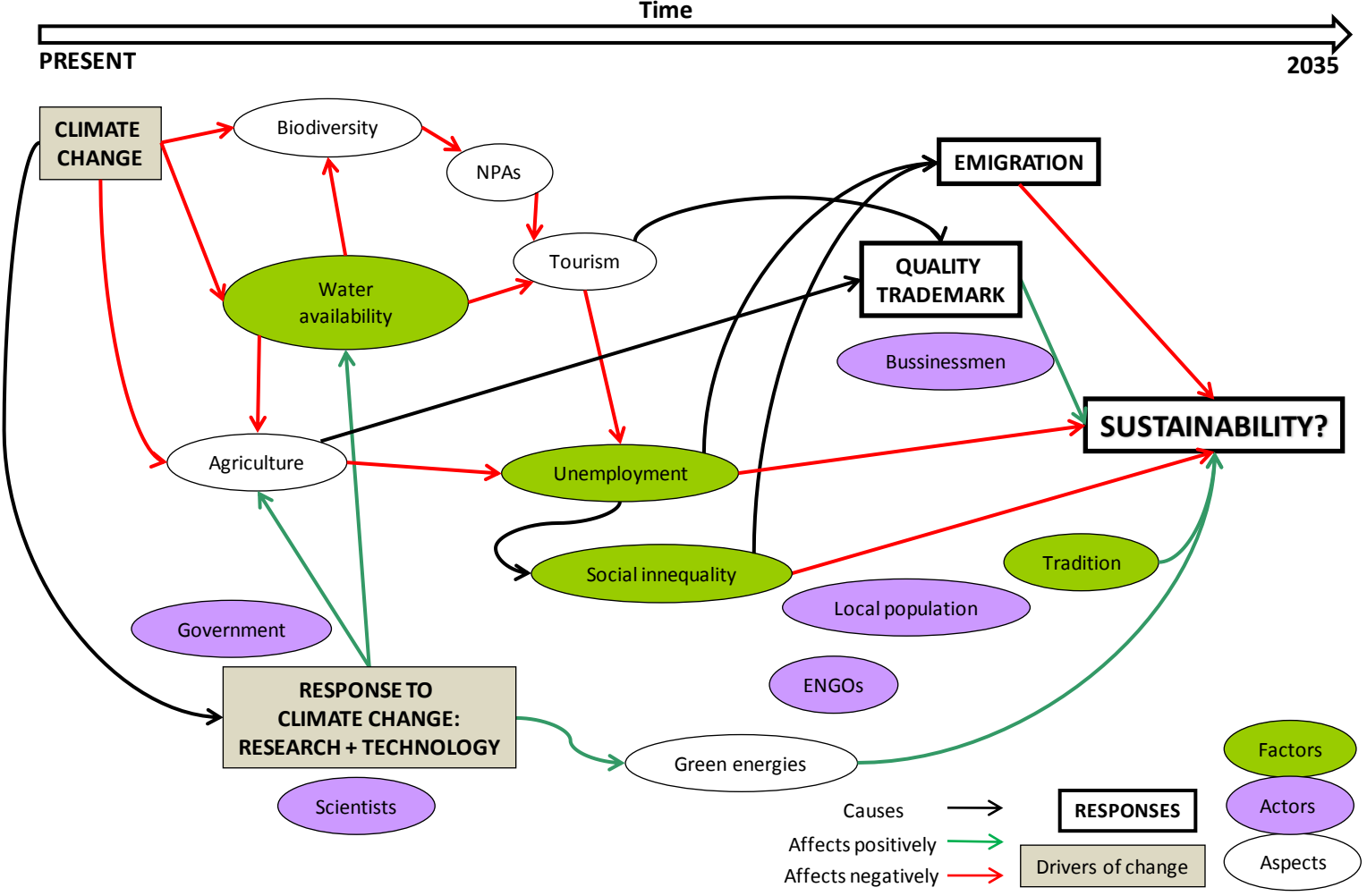




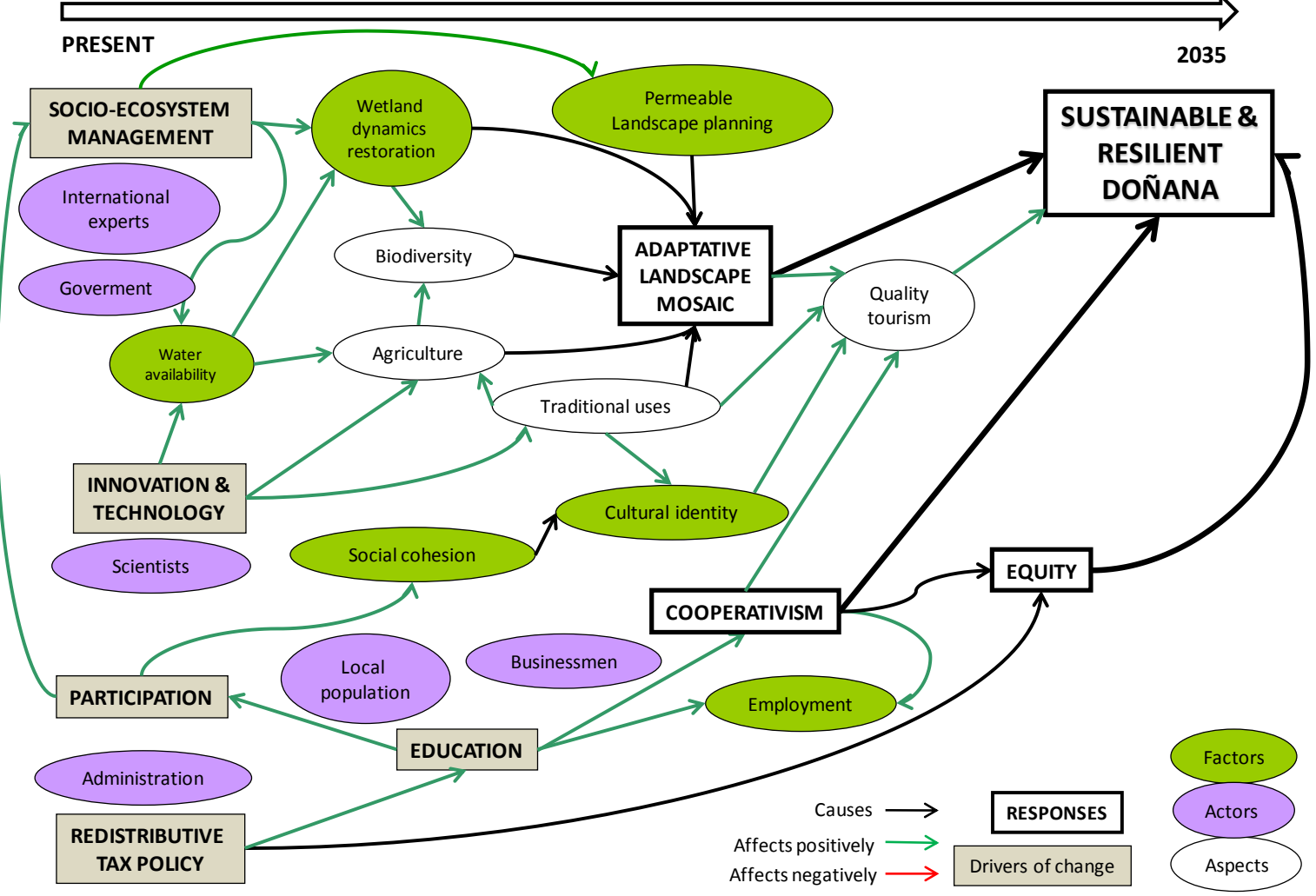


Table 1. Results of the feed-back questionnaires of the workshops.

Ecology and Society 16(1): 23 http://www.ecologyandsociety.org/vol16/iss1/art23/

\begin{tabular}{|l|c|c|c|c|c|}
\cline { 2 - 6 } \multicolumn{1}{c|}{} & $\begin{array}{c}\text { Did you } \\
\text { attend the } \\
\text { first } \\
\text { workshop? }\end{array}$ & $\begin{array}{c}\text { Was the } \\
\text { workshop useful } \\
\text { to express your } \\
\text { opinion about } \\
\text { Doñana? }\end{array}$ & $\begin{array}{c}\text { Could you } \\
\text { express your } \\
\text { opinion freely? }\end{array}$ & $\begin{array}{c}\text { Do the results of your } \\
\text { scenario group reflect the } \\
\text { opinions of everyone in } \\
\text { your group? }\end{array}$ & $\begin{array}{c}\text { Would you like to } \\
\text { participate in } \\
\text { future workshops } \\
\text { about Doñana? }\end{array}$ \\
\hline $\begin{array}{l}\text { First } \\
\text { workshop } \\
\mathbf{( 5 / 1 5 / 2 0 0 9 )}\end{array}$ & $\begin{array}{c}\text { Very useful } \\
(33 \%), \text { Quite } \\
\text { useful (57\%), } \\
\text { Not so useful } \\
(10 \%)\end{array}$ & Yes (100\%) & Yes (95\%) & Yes (100\%) \\
\hline $\begin{array}{l}\text { Second } \\
\text { workshop } \\
(\mathbf{6} / \mathbf{2 4 / 2 0 0 9 )}\end{array}$ & Yes (40\%) & $\begin{array}{c}\text { Very useful } \\
(39 \%), \text { Quite } \\
\text { useful (48\%), } \\
\text { Not so useful } \\
(13 \%)\end{array}$ & Yes (96\%) & Yes (83\%) & Yes $(96 \%)$ \\
\hline
\end{tabular}

